\title{
ANOTHER LOOK AT UNCONSTITUTIONAL CONDITIONS
}

The doctrine of unconstitutional conditions is undergoing a revival and metamorphosis that have significantly expanded its application. Generally, the doctrine states that while a government, state or federal, may not be obligated to provide its citizens with a certain benefit or privilege, it may not grant the benefit or privilege on conditions requiring the recipient in some manner to relinquish his constitutional rights. ${ }^{1}$ Furthermore, it cannot withhold or cancel the benefit as a price for the assertion of such rights.

Recent cases have focused on the second aspect of the doctrine, that which proscribes penalizing the exercise of a constitutional right. ${ }^{2}$ The concern has been not only with the fundamental unfairness of any such penalty, ${ }^{3}$ but also with the deterrent effect that the exaction of such a price has on the exercise of the right. ${ }^{4}$ Denial of the benefit to individuals operates as a subtle but nonetheless potent form of compulsion on them to forego asserting their constitutional rights. ${ }^{5}$

As government has become increasingly involved in supplying such vital benefits to the population as jobs, housing, welfare, and education, ${ }^{6}$ opportunities for substantial inhibition and suppression of the exercise of constitutional rights have multiplied. While the relevance of the doctrine of unconstitutional conditions to such areas of governmental bounty and activity have been explored elsewhere, ${ }^{7}$

1 For general discussions of the early cases expounding the doctrine see Hale, Unconstitutional Conditions and Constitutional Rights, 35 CoLUM. L. REv. 321 (1935); Merrill, Unconstitutional Conditions, 77 U. PA. L. REV. 879 (1929); Oppenheim, Unconstitutional Conditions and State Powers, 26 MrCE. L. Rev. 176 (1927). For more recent treatments see French, Unconstitutional Conditions: An Analysis, 50 GEo. L. J. 234 (1961); O'Neill, Unconstitutional Conditions: Welfare Benefits with Strings Attached, 54 CALIF. L. Rev. 443 (1966); Wilcox, Invasions of the First Amendment Through Conditioned Public Spending, 41 CoRNELL L.Q. 12 (1955); Note, Unconstitutional Conditions, 73 HARv. L. REv. 1595 (1960) ; Note, Judicial Acquiescence in the Forfeiture of Constitutional Rights Through Expansion of the Conditioned Privilege Doctrine, 28 IND. L.J. 520 (1953).

2 See, e.g., United States v. Jackson, 390 U.S. 570 (1968) ; Spevack v. Klein, 385 U.S. 511, 515 (1967); Patton v. North Carolina, 381 F.2d 636 (4th Cir. 1967), cert. denied, 390 U.S. 905 (1968); Smartt v. Avery, 370 F.2d 788, 799 (6th Cir. 1967); cf. Griffin v. California, 380 U.S. 609,614 (1965).

${ }^{3}$ See Patton v. North Carolina, 381 F.2d 636 (4th Cir. 1967), cert. denied, 390 U.S. 905 (1968).

4 See United States v. Jackson, 390 U.S. 570, 581 (1968); Garrity v. New Jersey, 385 U.S. 493, 496-97 (1967) ; Patton v. North Carolina, 381 F.2d 636, 639 (4th Cir. 1967), cert. denied, 390 U.S. 905 (1968) ; Smartt v. Avery, 370 F.2d 788, 790 (6th Cir. 1967).

5 See Garrity v. New Jersey, 385 U.S. 493, 496 (1967) ; Spevack v. Klein, 385 U.S. 511,516 (1967).

${ }^{6}$ On the scope and significance of governmental largess, see Reich, Individual Rights and Social Welfare: The Emerging Legal Issues, 74 Ý ALE L.J. 1245 (1965); Reich, The New Property, 73 Y ALE L.J. 733, 779-82 (1964).

7 See generally O'Neill, supra note 1 ; Wilcox, supra note 1. 
this Comment will focus primarily on the doctrine's emerging applicability to the conditioning of more subtle forms of governmental benefits, such as leniency in sentencing, and allowance of probation. Factual situations in recent cases involving such benefits are strikingly different from those in which the doctrine of unconstitutional conditions originated. It is particularly important to isolate the delimiting factors in the doctrine in order to provide guideposts for its operation in new contexts.

\section{A GLANCE BaCKWARD}

The doctrine of unconstitutional conditions arose from a need to limit the notion that, since the government might completely withhold a particular benefit, it could therefore offer the benefit on any condition whatsoever. It was argued that the power to withhold necessarily included the lesser power to grant on chosen conditions. ${ }^{s}$ Since the individual could escape the condition by rejecting the benefit, it was reasoned that any restrictions on constitutional rights were voluntarily assumed by the recipient. ${ }^{9}$ Thus arose a distinction based on a dichotomy between right and privilege. Where a certain benefit could be labeled as one enjoyed as a matter of right, its enjoyment could not be arbitrarily conditioned; on the other hand, if the benefit were only a privilege bestowed at the grace of the state, conditioning would be permitted. ${ }^{10}$

Concern for the dilution of individual rights that might be effected through conditioned benefits was forcefully expressed by the Supreme Court as early as 1926:

If the state may compel the surrender of one constitutional right as a condition of its favor, it may, in like manner, compel a surrender of all. It is inconceivable that guaranties embedded in the Constitution of the United States may thus be manipulated out of existence. ${ }^{11}$

Accordingly, subsequent courts for the most part have not been persuaded by arguments founded upon the absolute power of government to withhold certain benefits. On the contrary, it has been recognized that the denial or revocation of benefits if certain conditions are not met is essentially regulatory activity by government, which must find compelling justification if constitutional rights are thereby restricted. ${ }^{12}$

8 E.g., Davis v. Massachusetts, 167 U.S. 43, 48 (1897). (1892).

9 McAuliffe v. Mayor of New Bedford, 155 Mass. 216, 220, 29 N.E. 517, 518

10 Packard v. Banton, 264 U.S. 140, 145 (1924).

11 Frost \& Frost Trucking Co. v. Railroad Comm'n, 271 U.S. 583, 594 (1926).

12 See cases cited notes 22 \& 23 infra. Iawson v. Housing Authority, $270 \mathrm{Wis}$. $269,276,70$ N.W.2d 605,609 , cert. denied, 350 U.S. 882 (1955), disparages the distinction between "vested rights" and "privileges." 
In discussing those contexts in which the doctrine of unconstitutional conditions has been successfully utilized to check assertions of unlimited governmental power, it is useful to delineate four broad areas of benefits and center attention on them: (1) the privilege of foreign corporations to engage in local business; (2) the use of public property and facilities; (3) the receipt of benefits; and (4) governmental employment.

\section{The Privilege of Foreign Corporations To Engage in Local Business}

Regulation of foreign corporations desirous of conducting business within a state provided the breeding ground for the doctrine of unconstitutional conditions. ${ }^{13}$ In 1839, the Supreme Court, in Bank of Augusta v. Earle, ${ }^{14}$ announced the rigid principle that a state has the power to exclude foreign corporations from conducting business within its borders. It was thought that from the power to exclude naturally flowed the power to allow entry on even the most unreasonable conditions ${ }^{15}$ and the power to revoke a corporation's license in a similarly arbitrary manner. Later, however, while still conceding that states could refuse permission to conduct local business, the Supreme Court held that a state could not grant the privilege on a condition that amounted to a tax on out-of-state corporate property without violating due process and imposing a restraint on interstate commerce. ${ }^{16}$ Erosion of the permissive approach of Bank of Augusta was continued by decisions restraining the state's power to condition a corporation's entry upon the waiver of the right to remove actions to the federal courts. It was first held that states could not specifically enforce such a waiver. ${ }^{17}$ In Terral v. Burke Construction Co., ${ }^{18}$ the Court went one

13 See generally G. Henderson, The Position of Foreign Corporations in AMERICAN Constitutional LaW 178-87 (1918). (1869).

1438 U.S. (13 Pet.) 519 (1839); see Paul v. Virginia, 75 U.S. (8 Wall.) 168

15 See Western Union Tel. Co. v. Kansas, 216 U.S. 1, 53-54 (1910) (Holmes, J., dissenting) ; Lafayette Ins. Co. v. French, 59 U.S. (18 How.) 404, 407 (1856).

16 Western Union Tel. Co. v. Kansas, 216 U.S. 1 (1910), which involved a franchise tax on a corporation's entire authorized capital stock. See Western Union Tel. Co. v. Foster, 247 U.S. 105 (1918); cf. Quaker City Cab Co. v. Pennsylvania, 277 U.S. $389,400-401$ (1928) (right to withhold permission from a foreign corporation to do local business did not enable state to condition privilege of entry on denial of equal protection through discriminatory taxation).

A state may not exclude a corporation from doing interstate business within its borders. Union Pac. R.R. v. Public Serv. Comm'n, 248 U.S. 67 (1918) ; Pullman Co. v. Kansas, 216 U.S. 56, 62 (1910) (decided two weeks after Western Union Tel. Co. v. Kansas, supra).

17 Insurance Co. v. Morse, 87 U.S. (20 Wall.) 445 (1874).

18257 U.S. 529 (1922), overruling Doyle v. Continental Ins. Co., 94 U.S. 535 (1876), and Security Mut. Life Ins. Co. v. Prewitt, 202 U.S. 246 (1906). The dissenting Justices in Security Mutual, supra, had emphatically stated: "In our view no state enactment can lawfully abridge this right or destroy it, directly or indirectly, by affixing heavy penalties to its assertion by those lawfully entitled to its enjoyment." 202 U.S. at 269 (Day \& Harlan, JJ., dissenting). 
step further and held that the state could not revoke the license because of the exercise of the right to removal.

These cases, which checked a power once thought to be virtually absolute, reflected the Court's increasing sensitivity to two basically national interests: unimpeded economic growth, and the smooth functioning of the federal system. It is not accidental that the doctrine was successfully invoked in support of a right so vital to corporate defense against local economic interests at a time of great national commercial expansion. ${ }^{19}$

\section{The Use of Public Property and Facilities}

The Court in Davis v. Massachusetts ${ }^{20}$ upheld an ordinance that prohibited public speaking in a municipal park without a permit from the mayor. The rationale of the decision was that since ownership of the land gave the municipality the right to withhold access completely, it could grant access on any conditions, including those restricting first amendment freedoms. ${ }^{21}$ Such superficial and deceptive logic was later vitiated by cases that viewed the manipulation of access to public property, especially city streets and traffic ways, as affirmative regulatory activity subject to constitutional attack. Burdens on free communication of ideas have been found in governmental conditions restricting the dissemination of literature and opinion, ${ }^{22}$ and the vesting of administrative officials with broad power to restrict the distribution of pamphlets and handbills. ${ }^{23}$ Control over access to state property has also been held insufficient justification for the conversion by legislative fiat of a private intrastate trucking company into a common carrier subject to increased regulation and public liabilities. ${ }^{24}$ Such an act was held to be a violation of the constitutional prohibitions

19 See Merrill, supra note 1, at 881-82; Oppenheim, supra note 1, at 178; Note, Unconstitutional Conditions, supra note 1 , at 1607 . An analogy to the invalidation of state regulation that thwarts the federal system has been found in the holding of ordinary contracts to be void as against public policy. See French, supra note 1, at 235 ; Hale, supra note 1 , at 325 .

20167 U.S. 43 (1897).

21 Id. at 48.

22 See Jamison v. Texas, 318 U.S. 413, 415-16 (1942); Schneider v. New Jersey, 308 U.S. 147, 162 (1939) ; Hague v. CIO, 307 U.S. 497, 514-516 (1939); cf. Saia v. New York, 334 U.S. 558, 561 n.2 (1948); Marsh v. Alabama, 326 U.S. 501, 505 (1946). These cases have effectively drained Davis of vitality, although it has not been overruled. Compare these cases with Adderly v. Florida, 385 U.S. 39 (1966), where the Court upheld restrictions on access to a jail driveway against first amendment objections.

23 See, e.g., Lovell v. Griffin, 303 U.S. 444, 451 (1938).

24 Frost \& Frost Trucking Co. v. Railroad Comm'n, 271 U.S. 583 (1926). The Court there relied on Michigan Pub. Util. Comm'n v. Duke, 266 U.S. 570 (1925), where a similar requirement imposed on a corporation doing exclusively interstate business was invalidated primarily because it imposed an "unreasonable condition precedent" to engaging in interstate commerce. Id. at 577. However, an alternative holding was that the condition converted property used exclusively in a private carrier business into a public utility by legislative fiat in violation of the due process clause of the fourteenth amendment. Id. at 578 . 
against taking property without just compensation and in an arbitrary manner. ${ }^{25}$

Danskin v. San Diego Unified School District ${ }^{26}$ invalidated a requirement that limited use of a school auditorium to persons subscribing to a loyalty oath. In compelling officials to allow public use without the condition, the California Supreme Court said: "A state is without power to impose an unconstitutional requirement as a condition for granting a privilege even though the privilege is the use of state property." 27 After probing the legislative justifications for the imposition of the condition, Mr. Justice Traynor concluded that

the Legislature denies access to . . . "subversive elements," not because it believes that their public meetings would create a clear and present danger to the community, but because it believes that the privilege of free assembly in a school building should be denied to those whose convictions and affiliations it does not tolerate. ${ }^{28}$

\section{The Receipt of Benefits}

A catalogue of the gratuitous benefits now offered by governmental agencies would be extensive. Possibilities for undermining individual liberties under such circumstances are of similar magnitude.

25 In Frost, the Court was bound by a construction of the California Supreme Court which announced what to the Court was a clearly improper statutory purpose of attempting to control competition. 271 U.S. at 591. This explains why what one might have expected to have been construed as a valid regulatory act of a state over intrastate commerce was nevertheless held to be an unconstitutional condition. Compare Frost with Stephenson v. Binford, 287 U.S. 251 (1932), and cases cited note 52 infra. 2628 Cal. 2d 536, 171 P.2d 885 (1946).

27 Id. at $545-46,171 \mathrm{P} .2 \mathrm{~d}$ at 891.

28 Id. at 545, 171 P.2d at 891 . In American Communications Ass'n v. Douds, 339 U.S. 382 (1950), the Supreme Court upheld a statute denying the use of National Labor Relations Board facilities to labor organizations whose officers failed to file non-Communist affidavits. This decision is characterized by judicial deference to the legislative judgment that the purposes of the benefits would be effectively subverted if persons with such beliefs were to gain access. The essential question was succinctly posed by Mr. Justice Frankfurter, who concurred in the Court's decision except as to its approval of certain vague, but separable parts of $\S 9(\mathrm{~h})$ of the Labor-Management Relations Act of 1947, ch. 120, 61 Stat. 146, repealed by Labor-Management Reporting and Disclosure Act of 1959, §201(d), 73 Stat. 525.

The essential question now is whether Congress may determine that mem-

bership of union officers in the Communist Party creates such an obvious

hazard to the peace-promoting purposes of the Act that access to the machinery

of the Act may be denied unions which prefer their freedom to have officers

who are Communists to their opportunities under the Act.

339 U.S. at 417-18 (Frankfurter, J., concurring).

However, United States v. Brown, 381 U.S. 437 (1965), implicitly overruled Donds on the point that Communists, or any named group, can be specifically singled out as dangerous to the labor movement and on that count deprived of a benefit. Brozen held that such a legislative judgment inflicted punishment without trial in violation of the constitutional prohibition against bills of attainder. Section 504 of the LaborManagement Reporting \& Disclosure Act of 1959, 29 U.S.C. \$ 504 (1964), which was the successor to $\S 9(\mathrm{~h})$, was held unconstitutional. This section, in addition to withholding union office from past and current members of the Communist Party, subjected them to prosecution. 381 U.S. at 458 . 
Cases where an unconstitutional condition analysis has been applied to forestall such an impact have involved such diverse benefits as unemployment compensation, ${ }^{29}$ welfare funds, ${ }^{30}$ public housing, ${ }^{31}$ tax exemptions, ${ }^{32}$ public education, ${ }^{33}$ and the mail service. ${ }^{34}$ Challenges directed to conditions attached to these benefits have usually been framed and sustained on a violation of first amendment freedoms, ${ }^{35}$ which in recent years have been zealously guarded against both direct and indirect invasion. ${ }^{36}$

With these benefits a high degree of relevance has been demanded between the imposition of the condition and the furtherance of the purposes of the benefit. For instance, in striking down a loyalty oath required pursuant to a federal statute dealing with public housing, one court stated:

Counsel for the defendant Authority have failed to point out to this court how the occupation of any units of a federally aided housing project by tenants who may be members of a subversive organization threatens the successful operation of such housing projects. ${ }^{37}$

\section{Governmental Employment}

Constitutional objection to requirements set for government employees was seemingly foreclosed by McAuliffe $v$. Mayor of New Bedford, ${ }^{3 s}$ where Oliver Wendell Holmes, then Chief Justice of the

29 Sherbert v. Verner, 374 U.S. 398, 404 (1963). See also Syrek v. California Unemployment Ins. Appeals Bd., 54 Cal. 2d 519, 532, 354 P.2d 625, 632, 7 Cal. Rptr. 97, 104 (1960).

30 Parrish v. Civil Serv. Comm'n, 66 Cal. 2d 260, 270, 425 P.2d 223, 230, 57 Cal. Rptr. 623, 630 (1967).

In Randolph v. United States, 274 F. Supp. 200 (M.D.N.C. 1967), aff'd per curiam, 389 U.S. 570 (1968), the plaintiff unsuccessfully argued that a requirement that all but nominal attorneys' fees in Social Security Act proceedings be approved by the Secretary for Health, Education, and Welfare effectively deprived an individual of the right to counsel because attorneys were discouraged from handling such cases. The court held, however, that there is no constitutionally protected right to counsel during administrative proceedings under the social security system. The court's analysis leaves something to be desired, since it reasoned from the premise that since Congress could entirely prohibit the use of attorneys during the proceedings, it could subject their fees to regulation.

31 Lawson v. Housing Authority, 270 Wis. 269, 70 N.W.2d 605, cert. denied, 350 U.S. 882 (1955).

32 First Unitarian Church v. County of Los Angeles, 357 U.S. 545 (1958) ; Speiser v. Randall, 357 U.S. 513, 519-20 (1958).

33 Dixon v. Alabama Bd. of Educ., 294 F.2d 150, 156 (5th Cir.), cert. denied, 368 U.S. 930 (1961).

34 Lamont v. Postmaster General, 381 U.S. 301, 309-10 (1965) (unconstitutional condition on first amendment rights to require addressee of certain subversive material to specifically request delivery of each piece of mail).

35 But see cases cited notes 30,33 supra.

36 See Sherbert v. Verner, 374 U.S. 398, 405 (1963).

37 Lawson v. Housing Authority, 270 Wis. 269, 287, 70 N.W.2d 605, 615, cert. denied, 350 U.S. 882 (1955); cf. Speiser v. Randall, 357 U.S. 513, 527 (1958).

38155 Mass. 216, 29 N.E. 517 (1892). 
Massachusetts Supreme Judicial Court, stated: "The Petitioner may have a constitutional right to talk politics, but he has no constitutional right to be a policeman." 39 Later courts, however, have found that both state and federal statutes may impose unconstitutional burdens on employees despite their inability to claim any abstract right to public employment. ${ }^{40}$ The focus has been on whether the condition bars individuals in a "patently arbitrary and discriminatory manner" in violation of due process ${ }^{41}$ and on whether, in withholding or revoking employment under conditions capable of sweeping and improper application, the state is violating specific constitutional freedoms by deterring or penalizing their exercise. ${ }^{42}$ In Elfbrandt $v$. Russell, ${ }^{43}$ the Supreme Court invalidated a state loyalty oath system that, in addition to denying employment to non-affiants, provided for discharge and perjury penalties for those who at the time of subscribing to the oath or afterwards were "knowing" members of an organization advocating the violent overthrow of the government. Penalizing "mere knowing membership," 44 without requiring a "specific intent" to further illegal aims, was found to infringe on first amendment freedoms by arriving at "guilt by association." 45 While in Elfbrandt the threat of subsequent prosecution loomed large to the Court, in a subsequent case a statutory loyalty clearance system applied to public school teachers was struck down for vagueness where the only apparent sanction for noncompliance or violation was dismissal or failure to hire. ${ }^{46}$

These decisions severely restrict the state's power to make association and belief a relevant consideration governing the fitness for employment of teachers, at least. They may cast doubt on the viability of the Court's decision in United Public Workers v. Mitchell, ${ }^{47}$ which upheld federal restrictions on political activities of civil servants. The conditions embodied in the Hatch Act ${ }^{48}$ were construed to be reasonable efforts by Congress to promote the efficiency, integrity, and dis-

39 Id. at 220,29 N.E. at 517.

40 See, e.g., Torasco v. Watkins, 367 U.S. 488, 496 (1961).

41 Wieman v. Updegraff, 344 U.S. 183, 194 (1952) (Black, J., concurring); see Baggett v. Bullitt, 377 U.S. 360, 369 (1964) ; Cramp v. Board of Pub. Instruction, 368 U.S. 278, 288 (1961) ; Slochower v, Board of Higher Educ., 350 U.S. 551, 557-58 (1956). The right to hold a specific employment and to follow a chosen profession free from unreasonable governmental interference comes within the "liberty" and "property" concepts of the fifth and fourteenth amendments. See Greene v. McElroy, 360 U.S. 474, 492 (1959).

42 E.g., Elfbrandt v. Russell, 384 U.S. 11 (1966). Again, the emphasis in recent years has been on first amendment freedoms. An extensive analysis of the constitutional infirmities of governmental loyalty oaths appears in Note, Loyalty Oaths, 77 YALE L.J. 739 (1968).

43384 U.S. 11 (1966).

$44 I d$. at 16.

45 Id. at 19.

46 Keyishian v. Board of Regents, 385 U.S. 589 (1967).

47330 U.S. 75 (1947).

4818 U.S.C. $\$ \$ 591-612$ (1964). 
cipline of the civil service. In view of the increasing tendency of the Court to override legislative judgment in the sensitive first amendment area, however, it is not unlikely that the envisioned danger to the public service and the public interest will pale in view of the broad sweep of the statute. ${ }^{49}$

\section{General Application of the Doctrine}

An examination of the cases involving arguments that unconstitutional conditions have been attached to state-proffered benefits indicates that the decisions have turned on analysis of four general variables: (1) the nature of the right affected, (2) the degree of infringement of the right, (3) the nature of the benefit offered, and (4) the strength and nature of the state's interest in conditioning the benefit.

As has been seen, the early cases evidence concern for the rights of corporations in situations where states exerted regulatory power that had a potentially disruptive effect on the federal system and the national economy. The apex of protection under the doctrine for rights bound up with economic interests was reached in Frost \& Frost Trucking Co. v. Railroad Commission, ${ }^{50}$ where a state statute regulating private carriers was held unconstitutional. The Court characterized the state's primary purpose as protection of the "business of those who are common carriers in fact by controlling competitive conditions." 51 While subsequent cases have eviscerated the holding of Frost in the context of state regulation of business, ${ }^{52}$ Frost has

49 See United States v. Robel, 389 U.S. 258 (1967), where a section of the Subversive Activities Control Act making it unlawful for any member of a Communistaction organization "to engage in any employment in any defense facility," was held to put a substantial burden on first amendment rights because it was drawn much more broadly than could be warranted by national security. Id. at 266 ; cf. Bagley v. Washington Township Hosp. Dist., 65 Cal. 2d 499, 421 P.2d 409, 55 Cal. Rptr. 401 (1966); Fort v. Civil Serv. Comm'n, 61 Cal 2d 331, 392 P.2d 385, 38 Cal. Rptr. 625 (1964). Pickering v. Board of Educ., 391 U.S. 563 (1968), offers enlightenment in its dicta. The Court held unconstitutional the dismissal of a school teacher for writing a letter, published in a local newspaper, containing false allegations critical of her superiors. The Court rejected the argument that public employment could be conditioned on the relinquishment of the first amendment right to comment on matters of public interest. But the Court stated:

At the same time it cannot be gainsaid that the State has interests as an employer in regulating the speech of its employees that differ significantly from those it possesses in connection with regulation of the speech of the citizenry in general. The problem in any case is to arrive at a balance between the interests of the teacher, as a citizen, ... and the interest of the State, as an employer, in promoting the efficiency of the public services it performs through its employees.

Id. at 568 .

50271 U.S. 583 (1926).

51 Id. at 591 .

52 See Fordham Bus Corp. v. United States, 41 F. Supp. 712, 715 (S.D.N.Y. 1941); notes $24 \& 25$ supra. See also the following decisions upholding state regulation of businesses over due process objections: Williamson v. Lee Optical Co., 348 U.S. 483 (1955); West Coast Hotel Co. v. Parrish, 300 U.S. 379 (1937); Nebbia v. New York, 291 U..S. 502 (1934). 
continuing vitality in its emphasis on the drastic effect that the conditioning of benefits can have on an individual's constitutional rights. ${ }^{53}$

The bulk of cases utilizing the unconstitutional condition analysis have involved first amendment freedoms. ${ }^{54}$ Presently, this is an area where even the most indirect invasions on rights will be given painstaking attention. In Sherbert $v$. Verner, ${ }^{55}$ the Court stated:

It is basic that no showing merely of a rational relationship to some colorable state interest would suffice; in this highly sensitive constitutional area, "[o]nly the gravest abuses, endangering paramount interests, give occasion for permissible limitation . . . " 56

The Court there held South Carolina's unemployment compensation act unconstitutional as applied to a Seventh Day Adventist who was excluded from benefits as not "available for work" 57 when she could not find a job releasing her from work on her sabbath, Saturday. Under the Court's analysis, withholding benefits under such conditions created a pressure to forego religious practice and a burden tantamount to a fine, even though punitive intent was absent. ${ }^{58}$

Decisions concerning the gratuitous benefits provided by government, as well as contractual benefits such as employment, have struggled to find a justifiable relation between the benefit and a condition based on belief or advocacy. For example, while the disloyalty of employees in sensitive positions may under certain circumstances present a very real danger, it is difficult to discern the public threat posed by the possession of tax exemptions by disloyal individuals. Where governmental bounty is involved, some courts have found not only a lack of justification for the condition in terms of the purposes of the benefit, but further, an intentional suppression of first amendment rights. ${ }^{59}$

53 But see the remarks of one writer soon after the Frost decision, suggesting that the doctrine of unconstitutional conditions should have been confined in application to those privileges bound up with the federal system, leaving the doctrine of actual coercion to deal with individual rights: "In fact our whole societal order rests upon the presuppostion that in dealing with his fellows and with private organizations [the individual] will bargain away his constitutional immunities, and that the bargains will be given legal effect." Merrill, supra note 1, at 893 .

54 See, e.g., Lamont v. Postmaster General, 381 U.S. 301 (1965); Torasco v. Watkins, 367 U.S. 488 (1961) ; Bagley v. Washington Township Hosp. Dist., $65 \mathrm{Cal}$. 2d 499, 421 P.2d 409, 55 Cal. Rptr. 401 (1966) ; Fort v. Civil Serv. Comm'n, 61 Cal. 2d 331, 392 P.2d 385, 38 Cal. Rptr. 625 (1964); Danskin v. San Diego Unified School Dist., 28 Cal. 2d 536, 171 P.2d 885 (1946).

55374 U.S. 398 (1963).

$56 I d$. at 406 (quoting Thomas v. Collins, 323 U.S. 516, 530 (1945)). See also Konigsberg v. State Bar, 366 U.S. 36, 56-80 (1961) (Black, J., dissenting), expressing the viewpoint that no state interest can justify limitation on first amendment freedoms.

57374 U.S. at 400.

58 Id. at 404.

59 See, e.g., Lamont v. Postmaster General, 381 U.S. 301, 310 (1965) (Brennan, J., concurring); Speiser v. Randall, 357 U.S. 513, 519 (1958); Danskin v. San Diego Ứnified School Dist., 28 Cal. 2d 536, 546-48, 171 P.2d 885, $891-93$ (1946). 
While the nature of the right and the degree of infringement wrought by the state's requirement are of paramount importance, the validity of the requirement is also likely to be affected by the kind of benefit to which the condition is attached. The doctrine of unconstitutional conditions has most often been applied to broad-scale governmental benefits on which large numbers of people depend. In invalidating the requirement of a loyalty oath for occupancy of public housing, the Wisconsin Supreme Court noted that if

[a] government, or agency thereof, owned 90 per cent of the rental units available for private housing in the nation as a whole, or even in a particular state or municipality, the number of people subjected to pressure by such a plan, of requiring a certificate of non-membership as a condition of tenancy, would be very considerable. ${ }^{60}$

Influenced by such considerations, the Supreme Court, in ruling certain applications and constructions of the federal postal law unconstitutional, has stressed the indispensability of the postal system to individuals. In Lamont v. Postmaster General, ${ }^{61}$ the Court noted that the use of the mails is almost as much a part of free speech as the right to use our tongues, and observed:

"Whatever may have been the voluntary nature of the postal system in the period of its establishment, it is now the main artery through which the business, social, and personal affairs of the people are conducted and upon which depends in a greater degree than upon any other activity of government the promotion of the general welfare." 62

Another distinct area of benefits the courts have guarded against unconstitutional conditions is that involving livelihood, including professional and occupational licenses, governmental employment, and unemployment compensation. The threat of disbarment, for instance, has been considered by the Supreme Court to be a powerful instrument of compulsion to make a lawyer relinquish his privilege against selfincrimination. $^{63}$ And the choice between forfeiting a job or incriminating oneself has been held to produce "coerced" statements in-

60 Lawson v. Housing Authority, 270 Wis. 269, 275, 70 N.W.2d 605, 609, cert. denied, 350 U.S. 882 (1955).

61381 U.S. 301 (1965). See also Hannegan v. Esquire, Inc., 327 U.S. 146, 156 (1946), where the Court construed a condition attached to a benefit (a subsidy granted through lower second-class postal rates) narrowly in order to avoid "grave constitutional questions." See United States ex rel. Milwaukee Social Democratic Publishing Co. v. Burleson, 255 U.S. 407, 430-32, 437-38 (1921) (Holmes \& Brandeis, JJ., dissenting).

62381 U.S. at 305 n.3, quoting Pike v. Walker, 121 F.2d 37, 39 (D.C. Cir. 1941).

63 See Spevack v. Klein, 385 U.S. 511, 516 (1967), discussed at notes 161-63 infra and accompanying text. 
admissible for evidentiary purposes. ${ }^{64}$ Similar emphasis on the importance of a benefit to the individual involved is evident in Sherbert v. Verner, ${ }^{65}$ where the Court alluded to the unmistakable pressure to forego religious practice inherent in the withholding of unemployment benefits. ${ }^{66}$

Generally, the less essential the benefit being denied to an individual for exercising (or refusing to waive) a constitutional right, the less likely it is that courts will find a condition attached to it unconstitutional. When conditions are attached to benefits about which individuals are relatively indifferent, the potential for coercion is obviously small. Thus, individual choice is relatively unfettered. The element that tips the scales to indicate an unconstitutional condition is deterrent potential, ${ }^{67}$ which can only be significant to the extent that an individual is reluctant to forego the benefit.

Although a compelling state interest may justify upholding a condition in many cases, if the condition is directed at suppressing individual liberties protected by the Constitution, it will always fall. ${ }^{.8}$ First, the condition will have little if any relevance to the fulfillment of any legitimate interests a state may have had in offering the benefit. Second, it would seem a clear violation of due process for the state

64 Garrity v. New Jersey, 385 U.S. 493, 496-97 (1967), discussed at notes 147-60 infra and accompanying text.

65374 U.S. 398 (1963).

$66 I d$. at 404.

67 See Sherbert v. Verner, 374 U.S. 398, 404 (1963) ; cf. United States v. Jackson, 390 U.S. 570, 581-85 (1968).

68 Consider the remarks of Mr. Justice Stewart, writing for the majority in United States v. Jackson, 390 U.S. 570, $581-82$ (1968) :

If the provision had no other purpose or effect than to chill the assertion of constitutional rights by penalizing those who choose to exercise them, then it would be patently unconstitutional. But, as the Government notes, limiting the death penalty to cases where the jury recommends its imposition does have another objective: It avoids the more drastic alternative of mandatory capital punishment in every case.

The Court held the condition invalid, in spite of the "legitimate" legislative goal, because it needlessly penalized the assertion of fifth and sixth amendment rights when there existed alternative methods, not burdening constitutional rights, for achieving the goal.

In United States v. O'Brien, 391 U.S. 367 (1968), the Court may have clarified its position on the relevance of legislative motive to the constitutionality of a statute. The federal prohibition against destroying draft cards was upheld as effectuating a substantial administrative interest of the Government by appropriately narrow means. The Court refused to examine the legislative motive, stating: "It is a familiar principle of constitutional law that this Court will not strike down an otherwise constitutional statute on the basis of an alleged illicit legislative motive." Id. at 383 . However, the Court distinguished those cases where "the inevitable effect of a statute on its face may render it unconstitutional," $i d$. at 384 , and also carved out bill of attainder cases where "the very nature of the constitutional question" requires such an inquiry. Id. at 383 n.30.

The Court nevertheless went on to examine evidence on congressional motives, and found it inconclusive, $i d$. at 385-86, a conclusion characterized by one commentator as "unsupportable." Emerson, Freedom of Expression in Wartime, 116 U. PA. L. REv. 975, 1001 n.82 (1968). 
to intentionally punish constitutionally protected conduct. ${ }^{89}$ Thus, in Speiser v. Randall, ${ }^{70}$ the Court implied that denial of the veterans' tax exemption because of expression that could not be the basis for criminal prosecution would be prohibited under the first amendment. ${ }^{71}$ Because the Court could find no recognizable danger to any legitimate state interest posed by disloyal veterans' possessing tax benefits, ${ }^{72}$ denial was recognized to be a form of punishment. Had such an interest been shown, the Court might have viewed the penalty as incidental and indirect and gone on to weigh the substantiality of the first amendment infringement against the significance of the state's interest. ${ }^{73}$ Similarly, in the earlier case of Hague v. CIO, ${ }^{74}$ the Supreme Court had viewed the matter in much the same way. The ordinance in question forbade the distribution of printed matter and the holding of meetings in streets and public places without a permit. ${ }^{75}$ The state apparently sought to justify the ordinance as a "general measure to

69 See Steinberg v. United States, 163 F. Supp. 590, 592 (Ct. Cl. 1958), where the court held unconstitutional a statute denying a retirement annuity to anyone invoking the fifth amendment before a federal investigating committee, because it was based on an arbitrary and unreasonable discrimination. Cf. Slochower v. Board of Higher Educ., 350 U.S. 551 (1956). An alternative holding was that the act constituted a bill of attainder since it inflicted punishment without trial of guilt. $163 \mathrm{~F}$. Supp. at 592. But cf. Clay v. United States, No. 24991, at 41-48 (5th Cir. May 6, 1968); Thompson v. Gleason, 317 F.2d 901, 907 (D.C. Cir. 1962). On bill of attainders, see generally Comment, The Supreme Court's Bill of Attainder Doctrine: A Need for Clarification, 54 CALIF. L. REv. 212 (1966); Note, The Bill of Attainder Clanses and Legislative and Administrative Suppression of "Subversives," 67 ColUM. L. Rev. 1490 (1967).

70357 U.S. 513 (1958).

71 Id. at $518-19$.

72 Characterizing the statutory purpose as punitive, the Court accepted the California Supreme Court's construction of the oath as barring only those who could be criminally punished for advocacy. Id. at. 519. It held that procedural due process was violated by requiring those the state sought to punish to bear the burden of proving their innocence.

It would seem, however, that the Supreme Court's decision in Flemming v. Nestor, 363 U.S. 603 (1960), is inconsistent with Speiser. Flemming held it not a violation of the fifth amendment due process clause to deny accrued old-age social security benefits to the resident wife of an alien who had been deported for engaging in Communist activities. His activities could not have been a basis for forfeiture or deportation either at the time they occurred or at the time he began participating in the social security program. Yet, the Court reasoned that since the Government was only "withholding . . a noncontractual benefit under a social welfare program," id. at 611, no vested right was withdrawn, and thus due process was not violated. Furthermore, since withdrawal of such a benefit did not constitute punishment, the statute was not a bill of attainder. Id. at 619. Speiser, on the other hand, avoids reasoning from such conclusory terms as "vested rights." See 357 U.S. at 518. United States v. Brown, 381 U.S. 437, 448 (1965), indicates that the Court is taking a more expansive approach to the concept of punishment.

73 The Speiser Court, for example, distinguished American Communications Ass'n v. Douds, 339 U.S. 382 (1950), on the basis that although the conditions there did in fact discourage the exercise of first amendment freedoms, the regulation was justified in order to prevent the purposes of the benefit from being undermined and the benefit from being used to the detriment of the public. 357 U.S. at 527 ; see note 28 supra; Konigsberg v. State Bar, 366 U.S. 36, 54 (1961), where Mr. Justice Harlan stated that Speiser was "explicitly limited so as not to reach cases where, as here, there is no showing of an intent to penalize beliefs."

74307 U.S. 496 (1939).

75 Id. at 515 . 
promote the public convenience in the use of the streets or parks," 76 but the Court characterized it as "directed solely at the exercise of the right of speech and assembly." 77

Even though there is a recognizably detrimental effect on constitutional rights, when a concrete state interest exists the use of a balancing test is inescapable. Where a court is dealing with a legislative enactment, a presumption of the validity of legislative judgment must be recognized. ${ }^{78}$ But even though the statute may effectuate a legitimate state interest, if it needlessly burdens the assertion of rights, it is constitutionally defective. ${ }^{79}$

Perhaps the clearest statement of the factors to be weighed is in Bagley v. Washington Township Hospital District, ${ }^{80}$ where the California Supreme Court invalidated a provision of the state's civil service statute prohibiting political activity and reinstated a nurse dismissed under the statute. The court stated:

Not only must the conditions annexed to the enjoyment of a publicly-conferred benefit reasonably tend to further the purposes sought by conferment of that benefit but also the utility of imposing the conditions must manifestly outweigh any resulting impairment of constitutional rights. Further, in imposing conditions upon the enjoyment of publicly conferred benefits, as in the restriction of constitutional rights by more direct means, the state must establish the unavailability of less offensive alternatives and demonstrate that the conditions are drawn with narrow specificity, restricting the exercise of constitutional rights only to the extent necessary to maintain the integrity of the program which confers the benefits. ${ }^{81}$

United States Supreme Court cases have particularly emphasized that aspect of the test which requires that conditions be narrowly

76 Id.

77 Id.

78 In Flemming v. Nestor, 363 U.S. 603, 617 (1960), for instance, the Court obviously felt constrained by legislative judgment in upholding the act under the government's power to tax for the general welfare. $C f$. note 72 supra.

79 See United States v. Jackson, 390 U.S. 570, 581-82 (1968), quoted note 68, stura. The Supreme Court there adopted an approach similar to that taken in Dean Milk Co. v. City of Madison, 340 U.S. 349 (1951), which typifies the application of the doctrine of the "reasonable alternative" in constitutional law in areas of conflict between federal commerce power and state regulation.

Excessive intrusion into private interests has been considered to be an independent due process ground for invalidation. See Struve, Less-Restrictive Alternative Principle and Economic Due Process, 80 HARv. L. REv. 1463 (1967). Additionally, it has led to a finding of overbreadth in statutes dealing with constitutionally sheltered first amendment activities. See, e.g., Shelton v. Tucker, 364 U.S. 479, 488 (1960). See generally Ratner, The Function of the Due Process Clause, 116 U. PA. L. REv. 1048, 1082-93 (1968). Jackson considerably extends the potential application of the doctrine.

80 65 Cal. 2d 499, 421 P.2d 409, 55 Cal. Rptr. 401 (1966).

81 Id. at 506, 421 P.2d at 415,55 Cal. Rptr. at 407 (footnotes omitted). 
drawn to meet the envisioned danger. Statutes drawn in terms so broad as to be capable of excluding from the benefit those who would not endanger its purposes have been invalidated, ${ }^{82}$ as have statutes embodying such vague standards that an individual must guess as to what conduct may or may not cause him to lose the benefit. ${ }^{83}$

In addition to any argument based on a violation of a substantive constitutional right, it may be argued that a particular condition employs an arbitrary and irrational classification and thus deprives those injured of equal protection of the laws. ${ }^{\text {s4 }}$ For example, a poll tax was struck down because qualifications on voting based on economic criteria were considered to be without rational justification. ${ }^{85}$ Furthermore, receipt of a benefit may evidently not be conditioned on the relinquishment of procedural due process in its administration. For example, it has been held that the privilege of attending a public educational institution cannot be withdrawn from a student without notice and opportunity for a hearing. ${ }^{86}$

82 See, e.g., United States v. Robel, 389 U.S. 258 (1967) ; Elfbrandt v. Russell, 384 U.S. 11 (1967); Shelton v. Tucker, 364 U.S. 479 (1960).

83 See Whitehill v. Elkins, 389 U.S. 54 (1967) ; Keyishian v. Board of Regents, 385 U.S. 589 (1967) ; Baggett v. Bullitt, 377 U.S. 360 (1964).

84 In Patton v. North Carolina, 381 F.2d 636 (4th Cir. 1967), cert. denied, 390 U.S. 905 (1968), the alternative ground for decision was that subjecting only defendants appealing their convictions to the risk of a harsher sentence than originally imposed was a violation of the equal protection clause because the distinction thus made was not rational. See notes 127-29 infra and accompanying text; cf. Rinaldi v. Yeager, 384 U.S. 305 (1966), holding that conditioning allowance of transcripts of court proceedings on repayment out of prison salary by unsuccessful appellants violated the equal protection clause. Not required to pay were those who had been fined, released on probation, or given suspended sentences. The Court left open the question whether the statute was a violation of equal protection or due process because it discouraged appeal by penalizing unsuccessful appellants. Id. at 307-08.

85 Harper v. Virginia State Bd. of Elections, 383 U.S. 663 (1966).

In United States v. Seeger, 326 F.2d 846, 854 (2d Cir.), rev'd, 380 U.S. 163 (1964), the circuit court invalidated the federal requirement that an individual must believe in a supreme being in order to gain conscientious objector status for the armed services. The condition was held to be an arbitrary and impermissible classification. The Supreme Court, however, adopted a broad reading of "Supreme Being" and thereby avoided the constitutional question. Had that not been possible, Mr. Justice Douglas' concurring opinion indicates that due process and equal protection problems would have arisen:

If I read the statute differently from the Court, I would have difficulties.

For then those who embraced one religious faith rather than another would be subject to penalties; and that kind of discrimination, as we held in Sherbert v. Verner, would violate the Free Exercise Clause of the First Amendment. It would also result in a denial of equal protection by preferring some religions over others-an invidious discrimination that would run afoul of the Due Process Clause of the Fifth Amendment.

380 U.S. at 188 (Douglas, J., concurring) (citations omitted).

se Dixon v. Alabama State Bd. of Educ., 294 F.2d 150, 156 (5th Cir.), cert. denied, 368 U.S. 930 (1961). The court was especially sensitive to the significance of the benefit: "Without sufficient education the plaintiffs would not be able to earn an adequate livelihood, to enjoy life to the fullest, or to fulfill as completely as possible the duties and responsibilities of good citizens." 294 F.2d at 157; see Willner v. Committee on Character \& Fitness, 373 U.S. 96, 102 (1963) (procedural safeguards required when denying admission to the bar); cf. Speiser v. Randall, 357 U.S. 518 (1958) (burden of proof is on group seeking to withhold the benefit). 
To discuss such cases in terms of unconstitutional conditions is indirect and unilluminating, because the core question will still remain: whether, in proffering a benefit with a condition attached, due process or equal protection is being denied. Where, however, the concern is with discouragement of the exercise of specifically enumerated constitutional rights, the analysis is aided by injecting the concept of conditioned benefits, for it focuses attention on the pressures inhibiting free exercise of those rights.

\section{Operation of the Doctrine in Recent Cases}

\section{Infringement Through Discouragement}

As has been seen, it is no answer to the problem posed by benefits conditioned on a waiver of constitutional rights to say that, since the recipient can reject the benefit and retain his rights, his rights are not abridged. Unless the benefit is inconsequential, he will be under strong pressure to accept the benefit, and it is fair to say that the state (whether intentionally or not) is encouraging him to forego exercise of his rights. That there exists an element of coercion in this situation was first clearly articulated by the Supreme Court in Frost \& Frost Trucking Co. v. Railroad Commission: ${ }^{87}$

[C]onstitutional guaranties, so carefully safeguarded against direct assault, are open to destruction by the indirect but no less effective process of requiring a surrender, which, though, in form voluntary, in fact lacks none of the elements of compulsion. Having regard to form alone, the act here is an offer to the private carrier of a privilege, which the state may grant or deny, upon a condition, which the carrier is free to accept or reject. In reality, the carrier is given no choice, except a choice between the rock and the whirlpool,an option to forego a privilege which may be vital to his livelihood or submit to a requirement which may constitute an intolerable burden. ${ }^{88}$

This thread of thought was picked up in Garrity v. New Jersey, ${ }^{89}$ where a state conviction of two policemen was overturned on the grounds that the incriminating statements utilized at trial were the product of coercion and therefore inadmissible as evidence under the fourteenth amendment. The statements had been elicited under the threat of a state statute requiring the dismissal of a state employee who refused before an official investigating committee to answer material questions related to his employment. ${ }^{.0}$ 
It is significant here that the Supreme Court characterized the choice between forfeiting one's job or incriminating oneself as the "antithesis of free choice to speak out or to remain silent." 91 In a companion case involving a lawyer, the Court found the threat of disbarment a powerful form of compulsion to relinquish the privilege against self-incrimination. ${ }^{92}$

These considerations have appeared in several recent criminal cases. The Fourth Circuit has declared the practice of allowing harsher sentences at retrials of defendants who had constitutionally defective first trials to present an unconstitutional condition: ${ }^{93}$

North Carolina deprives the accused of the constitutional right to a fair trial, then dares him to assert his right by threatening him with the risk of a longer sentence. It may not exact this price. Enjoyment of a benefit or protection provided by law cannot be conditioned upon the "waiver" of a constitutional right. ${ }^{94}$

Similarly, the Sixth Circuit struck down a Tennessee statute providing that unsuccessful habeas corpus applicants in state or federal courts would not be eligible to be considered for probation consideration until a year beyond the usual time. ${ }^{95}$ Just as the state cannot directly interfere with the right to petition the federal courts for a writ of habeas corpus, ${ }^{96}$ the court reasoned, the state cannot discourage its exercise by withholding a privilege that would otherwise be accorded by state law. The court observed: "Only a prisoner with an inclination to play Russian roulette with a year of his life would be likely to file a petition for writ of habeas corpus under this regulation." 97 The same consideration was apparent in United States $v$. Jackson. ${ }^{98}$ The federal kidnaping statute prescribed the death penalty only "if the verdict of the jury shall so recommend." 99 On its face, it imposed an unwarranted burden on the exercise of the right to jury trial, thereby serving

91 Id. at 497.

92 Spevack v. Klein, 385 U.S. 511,516 (1967). (1968).

93 Patton v. North Carolina, 381 F.2d 636 (4th Cir.), cert. denied, 390 U.S. 905

94381 F.2d at 640 (footnote omitted) ; accord, Gainey v. Turner, 266 F. Supp. 95 (E.D.N.C. 1967); see Marano v. United States, 374 F.2d 583 (1st Cir. 1967). But see United States ex rel. Starner v. Russell, 378 F.2d 808 (3d Cir.), cert. denied, 389 U.S. 889 (1967) ; Shear v. Boles, 263 F. Supp. 855 (N.D. W. Va.), rev'd per curiam, 391 F.2d 609 (4th Cir. 1967), cert. denied, 390 U.S. 981 (1968) ; cf. United States v. White, 382 F.2d 445 (7th Cir. 1967), cert. denied, 389 U.S. 1052 (1968). The "benefit or protection" referred to is the state's refraining from opening the sentence for possible revision.

95 Smartt v. Avery, 370 F.2d 788 (6th Cir. 1967).

98 "[T] he state and its officers may not abridge or impair petitioner's right to apply to a federal court for a writ of habeas corpus." Ex parte Hull, 312 U.S. 546, 549 (1941).

07 Id. at 790.

08390 U.S. 570 (1968).

8918 U.S.C. \$1201(a) (1964). 
to encourage defendants either to plead guilty or to waive jury trial in order to avoid the death penalty. ${ }^{100}$

These decisions evidence concern for what may be termed infringement of a constitutional right through discouragement of its exercise. ${ }^{101}$ The discouragement comes about through the placing of a penalty on the assertion of the right and hence a premium on its waiver. Common sense would indicate that the result of such a combination is pressure. And, as the importance of the benefit to the individual increases, so proportionately increases the pressure.

This concept of infringement has been utilized especially in the area of criminal appeals and postconviction remedies. Although no court has yet found a constitutional right to appeal guaranteed by the due process clause, where the "privilege" exists it has been carefully protected by the courts. ${ }^{102}$ In Green $v$. United States, ${ }^{103}$ a defendant found guilty of second degree murder had successfully appealed his conviction and, upon retrial, had been convicted of first degree murder and sentenced to death. The Court held that the fifth amendment's prohibition against double jeopardy had been violated. Considering the judgment of second degree murder to include an implicit acquittal of the charge of first degree murder, the Court reasoned that the defendant could not be forced to waive his protection against double jeopardy as a condition of exercising the privilege of appeal.

The law should not, and in our judgment does not, place the defendant in such an incredible dilemma. Conditioning an appeal of one offense on a coerced surrender of a valid plea of former jeopardy on another offense exacts a forfeiture in plain conflict with the constitutional bar against double jeopardy. ${ }^{104}$

100390 U.S. at 583.

101 See id.: "Congress cannot impose such a penalty in a manner that needlessly penalizes the assertion of a constitutional right." But cf. id.: "For the evil in the federal statute is not that it necessarily coerces guilty pleas and jury waivers but simply that it needlessly encourages them." (Emphasis in original.) Some of the conceptual difficulty here perhaps stems from the fact that although the statute penalized only the exercise of the sixth amendment right to jury trial, it thereby encouraged waiver of both that right and the fifth amendment right to plead not guilty. Id. at 581-83.

102 See, e.g., Rinaldi v. Yeager, 384 U.S. 305 (1966) ; Fày v. Noia, 372 U.S. 391 (1963) ; Douglas v. California, 372 U.S. 353 (1963); Griffin v. Illinois, 351 U.S. 12 (1956). An interesting expression of the concern for unfettered appeals is Worcester v. Commissioner, 370 F.2d 713 (1st Cir. 1966), where a prior conviction, from which the defendant did not appeal because of a judge's promise to place him on probation if he did not seek review, was held to be tainted and not available to the government seeking collaterally to estop the defendant from disputing the issue of fraud in a subsequent tax case.

103355 U.S. 184 (1957).

104 Id. at 193-94 (footnote omitted) ; see People v. Henderson, 60 Cal. 2d 482, 497, 386 P.2d 677, 686, 35 Cal. Rptr. 77, 86 (1963) (applying Green rationale in construing state constitutional prohibition against double jeopardy):

A defendant's right of appeal from an erroneous judgment is unreasonably impaired when he is required to risk his life to invoke that right. Since the 
In an analogous situation, where sentence was passed in defendant's absence, and thus was a violation of procedural due process, the Fourth Circuit held it unconstitutional to condition correction of that sentence on the risk of a harsher one. ${ }^{105}$ The defendant had been sentenced in absentia to three years' imprisonment and placed on probation. After violating his probation, he was committed to serve out his term. He attacked the original sentence as invalid because of his absence; the challenge succeeded and he was placed on probation for five years. Again violating probation, he was sentenced (still on the original count) to five years' imprisonment. The court stated:

However, the import of the [District] Court's ruling was to condition his Constitutional right to seek correction upon the risk of another sentence, then unforeseeable in nature and extent. Thus, though not so intending, the Court potentially penalized him for asserting the privilege. . . ..$^{106}$

[The new sentence] was, in sum, the product of a procedure which could prove either deterring or punitive of an insistence on Constitutional privileges. ${ }^{107}$

From these cases, it is evident that arguments claiming infringement through discouragement have been accepted by the courts. Yet it is legitimate to ask whether discouragement constitutes a "clear, direct, and material infringement of a specific constitutional guarantee." 108 A preliminary question is: How does a court ascertain whether persons are discouraged from exercising rights as a result of the conditioned benefit? In the decisions discussed above, the courts seem simply to have been making a common-sense judgment, based primarily on consideration of the kind of benefit being manipulated. Thus, it is not difficult to imagine the deterrent effect of a prospective death sentence ${ }^{109}$ or even the revocation of a corporate license. ${ }^{110}$ The court in Patton v. North Carolina ${ }^{111}$ relied in part on statistics indicat-

state has no interest in preserving erroneous judgments, it has no interest in foreclosing appeals therefrom by imposing unreasonable conditions on the right to appeal.

105 United States v. Walker, 346 F.2d 428 (4th Cir. 1965).

$106 I d$. at 430 .

$107 \mathrm{Id}$. at 431.

108 This is the question posed by Oppenheim, Unconstitutional Conditions and State Pozvers, 26 MICH. L. REv. 176, 186 (1927), writing soon after the decision in Frost \& Frost Trucking Co. v. Railroad Comm'n, 271 U.S. 583 (1926).

109 In Fay v. Noia, 372 U.S. 391 (1963), the Supreme Court, in finding that the defendant had not knowingly and intelligently waived his right to appeal, explained the extreme power of that threat: "His was the grisly choice whether to sit content with life imprisonment or to travel the uncertain avenue of appeal which, if successful, might well have led to a retrial and death sentence. . . . He declined to play Russian roulette in this fashion." Id. at 440 (citation omitted).

110 See Terral v. Burke Constr. Co., 257 U.S. 529 (1922), discussed in text accompanying note 18 supra.

111381 F.2d 636 (4th Cir. 1967), cert. denied, 390 U.S. 905 (1968). 
ing the prevalence of harsher sentencing at North Carolina retrials, ${ }^{112}$ and also in part on a letter from a prisoner to the district judge indicating he was afraid to appeal. ${ }^{113}$

Patton illustrates that the conditioning of the benefit does not, of course, have to be embodied in an explicit statutory scheme. The potential penalty for appealing resulted from a judicial policy of viewing a defective trial (and the sentence passed pursuant to a judgment of guilt) as a nullity, leaving the new trial a tabula rasa. Furthermore, the burden arising from the situation was not the certain imposition of harsher sentence at retrial, but rather the threat of it. However, when the evil is viewed as the discouragement of the assertion of rights, this distinction becomes important only in considering the degree of discouragement.

In the first amendment area, in particular, courts have grappled with the concept of infringement through discouragement. In American Communications Association v. Douds, ${ }^{114}$ the Supreme Court said:

[T] he fact that no direct restraint or punishment is imposed upon speech or assembly does not determine the free speech question. Under some circumstances, indirect "discouragements" undoubtedly have the same coercive effect upon the exercise of First Amendment rights as imprisonment, fines, injunctions or taxes. ${ }^{115}$

But even though withholding or withdrawing a benefit may produce a substantial infringement of constitutional rights, there remains the further consideration of state interest. The pertinent inquiry is whether the state should be permitted to put the individual to the choice of giving up a benefit or giving up a constitutional right.

\section{Coercion}

The Supreme Court in Garrity v. New Jersey ${ }^{116}$ compared the conditions under which the policemen's statements had been made to those at which the rule of Miranda $v$. Arizona was directed, conditions "likely to exert such pressure upon an individual as to disable him from making a free and rational choice." 117 The Court char-

112381 F.2d at 639 n.8. The court cited a survey revealing that, in $72 \%$ of the retrials occasioned by the denial of counsel at the first trial, defendants were effectively denied credit for time served. Note, Constitntional Laze: Increased Sentence and Denial of Credit on Retrial Sustained Under Traditional Waiver Theory, 1965 DuKE L.J. 395,399 n. 25 .

113381 F.2d at 639 n.7.

114339 U.S. 382 (1950).

115 Id. at 402; see NAACP v. Alabama, 357 U.S. 449, 461 (1958).

116385 U.S. 493 (1967). at 497 .

117 Miranda v. Arizona, 384 U.S. 436, 464-65 (1966), quoted in Garrity, 385 U.S. 
acterized the issue simply in terms of coercion. But to discuss the issue in terms of actual coercion obscures the important balancing test that must be incorporated into any decision involving discouragement of the exercise of constitutional rights by withholding or revoking benefits. ${ }^{118}$

The dissenting opinion of Mr. Justice Harlan in Garrity expresses sensitivity to the majority's confusion:

The majority is apparently engaged in the delicate task of riding two unruly horses at once: it is presumably arguing simultaneously that the statements were involuntary as a matter of fact, in the same fashion that the statements in Chambers v. Florida and Haynes v. Washington were thought to be involuntary, and that the statements were inadmissible as a matter of law, on the premise that they were products of an impermissible condition imposed on the constitutional privilege. ${ }^{119}$

Difficult choices are not necessarily unfree ones. Whenever a benefit is important to a person, he is naturally going to be reluctant to jeopardize its continued enjoyment, but a choice based on such intense interest is not necessarily "coerced" in the legal sense. If it were thought to be, the term would be stretched beyond meaningful limits. While the deterrent effect on the individual vis-à-vis the assertion of his rights can be isolated as a rough form of coercion, the pressure should be tolerated when appropriately justified. When the practice of conditioning benefits operates to penalize the assertion of constitutional rights and has insufficient redeeming public purpose, ${ }^{120}$ then it must be eradicated by a protective ruling in much the same manner as was done in United States $v$. Jackson. ${ }^{21}$ In Jackson, the finding of pressure alone did not conclude the inquiry: "For the evil in the federal statute is not that it necessarily coerces guilty pleas and jury waivers but simply that it needlessly encourages them." 122

\section{The Balancing Process}

In Smartt v. Avery, ${ }^{123}$ the deterrent effect on the right to petition for writ of habeas corpus was sufficient reason for the court to invalidate the challenged regulation. No consideration of any state

118 Recently, the Supreme Court acknowledged the necessity to "arrive at a balance" where the free speech of teachers was in question. Pickering v. Board of Educ., 391 U.S. 563, 568 (1968), quoted at length in note 49 supra.

119385 U.S. at 501 (Harlan, J., dissenting) (citations omitted).

120 Of course, if the state's only interest is to discourage the assertion of constitutional rights, the condition is never permissible. See notes 68-69 supra.

121390 U.S. 570 (1968).

$122 I d$. at 583 (emphasis in original).

123370 F.2d 788 (6th Cir. 1967). 
interest is found in the opinion, perhaps because the state itself had difficulty mustering up a legitimate one. In view of the seeming irrelevance of petitioning for a writ of habeas corpus to the question of eligibility for probation, the only evident purpose of the statute was to penalize and thus deter the assertion of a federal right. ${ }^{124}$ The situation is comparable to the denial of tax exemptions to those with unpopular beliefs, ${ }^{125}$ or to the penalization by adverse comment at trial of those who exercise the right not to incriminate themselves. ${ }^{126}$

Invalidation of an inhibiting practice where the manifest intent and inevitable effect of the statute are not to punish the assertion of protected rights requires evaluation of the state interest. Several decisions evidence a failure to make a thorough examination. In Patton v. North Carolina, ${ }^{127}$ the Fourth Circuit held a harsher sentence meted out after retrial of a defendant to be constitutionally defective. The court utilized an unconstitutional condition analysis, but investigated possible state interests only under its alternative ground of denial of equal protection. State interest is relevant to both arguments, however. The court found that meting out harsher sentences on retrial was neither a rational system for sentence revision nor a rational means for discouraging frivolous appeals. Although sentence revision would be applied only to those who had pursued postconviction remedies, the court saw no reason why this group would be particularly likely to have unduly lenient sentences warranting review. ${ }^{128}$ Furthermore, rather than striking at those presenting frivolous appeals, the practice subjected only those whose appeals were successful to the possibility of harsher sentencing at retrial. ${ }^{129}$

124 See notes 68-69 supra and accompanying text. Also, consider the dissenting remarks of Mr. Justice Fortas in United States v. Ewell, 383 U.S. 116, 126 (1966) (joined by Douglas, J.), where the Supreme Court reinstated indictments dismissed below on the grounds of double jeopardy. The Court held that reindictment for additional offenses arising from an original indictment but not contained in it did not violate the fifth amendment's protection against double jeopardy. The dissenting Justices could not agree:

In the present case it appears that the purpose as well as the effect of the Government's action was to discourage the exercise of the right, conferred by statute, to seek review of criminal convictions. According to the District Court, the only reason advanced by the Government for the multiplication of charges against appellees was that the prosecutor wanted to discourage others convicted of narcotics offenses from attacking convictions.

Id. at 128. Further, Mr. Justice Fortas stated:

Apart from considerations of the impermissible purpose . . this technique has the necessary effect of unlawfully burdening and penalizing the exercise of the right to seek review of a criminal conviction under federal law. This, in my opinion, is forbidden by the Due Process Clause.

$I d$. at $129-30$.

125 See notes 70-72 supra and accompanying text.

126 See Griffin v. California, 380 U.S. 609 (1965).

127381 F.2d 636 (4th Cir. 1967), cert. deried, 390 U.S. 905 (1968).

128381 F.2d at 642 .

129 Id. at 643. Additionally, the court cited to an article which cogently and methodically destroys any possible arguments on behalf of state interests. Id. at 642 n.17 (quoting and citing Van Alstyne, In Gideon's Wake: Harsher Penalties and the 'Successful' Criminal Appellant, 74 YALE L.J. 606, 683 (1965)). 
Without evaluating the state's interests, the Patton court indicated that the means chosen were ill-suited to any possible legitimate ends and served to discourage the exercise of a constitutional right. ${ }^{130}$ A broad prohibitory rule was fashioned by the court: the sentence at the second trial can never be harsher than that at the first, at least where indictments are identical. ${ }^{131}$ The court recognized that certain circumstances might be revealed at a second trial which would warrant harsher punishment, but it stated:
Against the rare possibility of inadequacy [of punishment], greater weight must be given to the danger inherent in a system permitting stiffer sentences on retrial-that the added punishment was in reaction to the defendant's temerity in attacking the original conviction. Even the appearance of improper motivation is a disservice to the administration of justice. ${ }^{132}$

The court analogized the need for a broad prohibitory rule in Patton to the need the Supreme Court found in Gideon v. Wainwright ${ }^{133}$ eliminating the heavy chance of undetectable prejudice. ${ }^{134}$

A more finely honed rule might have been appropriate. The rule announced by the district court in Patton ${ }^{135}$-and also by the First Circuit in Marano v. United States ${ }^{136}$-may strike a better balance between remedying the constitutional infringement and the state's legitimate interest in providing sentences shaped to the individual case. Such a rule would require that there be substantial concrete justification in the record if a sentence is to be hiked. If sentences were adjusted only for meaningful differences at the second trial, appeals would not be discouraged to the same extent, for defendants would no longer be deterred by the spectre of purely retributive sentences by judges intent on discouraging appeals. Arguably, however, while the rule would be formally complied with by judges, the determination of actual judicial motivation would be so difficult that nothing short of Patton's broad rule would eliminate the discouragement. ${ }^{137}$

The decision of the Supreme Court in United States $v$. Jackson ${ }^{138}$

130 See note 79 supra, discussing the application of the least restrictive alternative principle in unconstitutional condition cases.

131381 F.2d at 641. But cf. United States v. Boyce, 352 F.2d 786 (4th Cir. 1965), where the court did not apply the Patton rationale because the second trial was a consolidation of the original indictment with others.

132381 F.2d at 641 .

133372 U.S. 335 (1963).

134 See id. at 344 .

135256 F. Supp. 225, 235 (W.D.N.C. 1966), noted in 80 HARv. L. REv. 891 (1967). 136374 F.2d 583 (1st Cir. 1967).

137 The problem of discouraging defendants by indicting them on additional counts still remains and has been held constitutionally permissible. See United States v. Ewell, 381 U.S. 116 (1966), discussed note 124 supra.

138390 U.S. 570 (1968). Subsequent to the decision in Jackson, the Court held the right to jury trial in "serious" criminal cases guaranteed against state denial by the due process clause of the fourteenth amendment. Duncan v. Louisiana, 391 U.S. 145 (1968). 
more thoroughly explored the government's interest even though the Court ultimately found that the procedure operated to discourage the assertion of the rights to trial and to trial by jury. The district court had dismissed the count of the indictment charging violation of the federal kidnaping act, ${ }^{139}$ holding the entire statute unconstitutional. The Supreme Court reversed and remanded, holding that the sentencing provision alone was unconstitutional and that it was severable from the rest of the statute. ${ }^{140}$ Rejecting the government's construction of the statute ${ }^{141}$ and its position that those defendants taking jury trial were not subjected to a substantially greater risk of receiving the death penalty than those taking trial by the court or pleading guilty, the Court found that the "[i] nevitable effect of . . . [the] provision [was] . . . to discourage assertion of the Fifth Amendment right not to plead guilty and to deter exercise of the Sixth Amendment right to demand a jury trial." 142

Acknowledging the existence of a congressional objective to ameliorate the severity of the capital punishment provision by allowing death to be dealt out only by a panel of twelve citizens, the Court found that the goal could have been effectuated by means which did not chill the exercise of constitutional rights. ${ }^{143}$ Thus, the availability of less

139 Whoever knowingly transports in interstate . . commerce, any person who has been unlawfully .. kidnaped . . . and held for ransom . . . or otherwise ... shall be punished (1) by death if the kidnaped person has not been liberated unharmed, and if the verdict of the jury shall so recommend, or (2) by imprisonment for any term of years or for life, if the death penalty is not imposed.

18 U.S.C. $\$ 1201$ (a) (1964) (emphasis supplied).

140 The Court refused to follow the government's suggestion to order all federal judges sitting in kidnaping cases to reject all guilty pleas and jury waivers. Although conceding that defendants had no constitutional right to plead guilty, the Court reasoned that the inauguration of such a drastic change in the administration of the statute should be done only pursuant to congressional direction. 390 U.S. at 584-85. The appellee's brief had argued that, although the statute or its administration could be remedied so as not to conflict with the exercise of constitutional rights, by invalidating the entire punishment provision the death penalty might be "nudged toward extinction" because Congress will have to re-enact the death penalty if it wishes to attach it to this crime. Brief for Appellee, at 24-25, United States v. Jackson, 390 U.S. 570 (1968).

141 The government urged that the risks for those taking trial by the different forms were not significantly different, because the statute (1) authorized a judge to empanel a jury solely for sentencing after a non-jury determination of guilt and (2) gave the judge discretion to nullify a jury's death sentence recommendation. 390 U.S. at 572-73. But the Supreme Court rejected both contentions and, after delving into the legislative history and cases, concluded that "the defendant who abandons the right to contest his guilt before a jury is assured that he cannot be executed [while] the defendant ingenuous enough to seek a jury acquittal stands forewarned that, if the jury finds him guilty and does not wish to spare his life, he will die." 390 U.S. at 581.

142 Id. (footnote omitted).

$143 \mathrm{~A}$ district court had stated that while it recognized that the statute places an obstacle in the path of the exercise of the right to jury trial, it was "necessary to compare the degree of the 'obstacle' against the value of the policy which it implements." Laboy v. New Jersey, 266 F. Supp. 581, 585 (D.N.J. 1967) (dictum). It concluded that the benefit from an essentially similar state procedure was sufficiently great that the court was not compelled to strike it down in favor of the "unobstructed choice of a trial by jury." Id. 
restrictive alternatives, such as leaving the choice between death or imprisonment to a jury in all cases, tipped the scales against the governmental interest. ${ }^{144}$

The issues involved in Garrity $v$. New Jersey ${ }^{145}$ and Spevak $v$. Klein ${ }^{146}$ are perhaps even more complex. Consideration of these cases involves not only the accommodation of competing state and individual interests, but also a determination of the precise scope of the constitutional privilege against self-incrimination. In Garrity, two policemen testified during a statewide investigation of traffic-ticket fixing. They had been advised of their fifth amendment right against selfincrimination, but were told that if they refused to answer any questions material to their employment, they would be fired under the state forfeiture-of-office statute. ${ }^{147}$ Their subsequent conviction on the basis of their testimony was upheld by the state supreme court. ${ }^{148}$

The Supreme Court reversed, holding that the threat of dismissal for nondisclosure rendered the resultant statements "involuntary" and hence inadmissible at trial. ${ }^{149}$ The Court proceeded from the articulation of the pressure inherent in the choice faced by the policemen to the conclusion that their statements were in fact coerced. Heretofore, the constitutional standard had been whether an inquiry into all the surrounding circumstances would lead to the conclusion that a defendant's will had 'been overborne and his capacity for selfdetermination critically impaired." 150 But as argued earlier, ${ }^{151}$ discussion in terms of coercion in fact inhibits an examination of the state interest that should be made in evaluating conditions placed on governmental benefits.

Underlying the evidentiary exclusion of statements produced through coercion has generally been the attempt to deter undesirable

144 In the Jackson opinion, the Court explicitly incorporated the requirement set out in first amendment cases for the evaluation of procedures challenged as unconstitutional discouragements: that the means be narrowly suited to the ends, at least when less restrictive means are available. 390 U.S. at 582 . See notes 68,79 supra and the third part of the Bagley formulation of the standards to be met by conditions attached to benefits, set out in text accompanying note 81 supra. Appellee's brief in Jackson emphasized the existence of other methods that would eliminate the differential risks producing the constitutional infirmity of the statute. For example, a special jury could be empaneled in all cases to determine punishment. Brief for Appellee at 26, United States v. Jackson, 390 U.S. 570 (1968). The defendant arguing before a jury that he is innocent could not practically argue that even if he is, he shouldn't receive the death penalty for certain reasons. Yet he could argue both propositions before separate juries. Id. at 24 . The brief argues, however, against the desirability of any type of jury sentencing. Id. at 26.

145385 U.S. 493 (1967).

146385 U.S. 511 (1967).

147 N.J. Rev. Stat. § 2A :81-17.1 (Supp. 1967).

148 State v. Naglee, 44 N.J. 209, 207 A.2d 689 (1966).

149385 U.S. at $497-98$.

150 Culombe v. Connecticut, 367 U.S. 568, 602 (1961); see Davis v. North Carolina, 384 U.S. 737, 742 (1966).

151 See text accompanying notes 116-22 supra. 
police tactics, rather than concern for factual reliability. ${ }^{152}$ But with Garrity, it is not realistic to characterize the attorney general's remarks to the policemen concerning dismissal as a reprehensible strong-arm procedure aimed at wearing down individual free will. The pressure that was admittedly brought to bear on the individuals was the product of a state legislative judgment that employees who do not cooperate in answering questions relevant to their official conduct should be dismissed. Behind this legislation were two primary state interests: first, the state's need to secure information from its employees about their official conduct, information that is normally only obtainable through their cooperation; and second, the state's desire to weed out disloyal and incompetent employees. The weeding is done by dismissing both those who will not disclose relevant information and those who are shown to be untrustworthy. ${ }^{153}$ However, these interests of the state as an employer are not advanced by utilization of the threat of prosecution on the basis of the information elicited. In fact, an employee faced with that prospect will be even more reluctant to talk, even though silence may mean the loss of his job.

As an enforcer of the criminal law, the state has an additional interest in prosecuting persons guilty of crime. But evidence obtained under threat of dismissal cannot be viewed in a vacuum. By its statutory policy the state encourages disclosure, and by so doing it discourages the assertion of the privilege against self-incrimination, even though the pressure cannot really be characterized as negating free will. In support of its decision in Garrity, the Court cited Miranda $v$. Arizona, ${ }^{154}$ where the Court had found that interrogation under certain circumstances was likely to discourage assertion of the right against self-incrimination ${ }^{155}$ and served no overriding state interest. ${ }^{150}$ The evidence was held inadmissible as a matter of law unless certain enunciated safeguards were followed. ${ }^{157}$ But the analogy is imperfect because in Miranda the state's interest was solely as prosecutor, while in Garrity, it was as employer as well. In Garrity a parallel safeguard might have been to forbid entirely the state's practice of firing for nondisclosure. To do so, however, would defeat the state's legitimate interest as employer. To condition the benefit

152 See Haynes v. Washington, 373 U.S. 503, 519 (1963) ; Rogers v. Richmond, 365 U.S. 534, 540-41 (1961). See also State v. Naglee, 44 N.J. 209, 218, 207 A.2d 689, 694 (1965), rev'd sub nom. Garrity v. New Jersey, 385 U.S. 493 (1967).

153 Helpful discussion of the competing state and individual interests appears in Ratner, Consequences of Exercising the Privilege Against Self-Incrimination, 24 U. Cri. L. Rev. 472, 493-511 (1957) ; 70 Harv. L. Rev. 120 (1956) ; Note, Mandatory Dismissal of Public Personnel and the Privilege Against Self-Incrimination, 101 U. PA. L. REv. 1190 (1953).

154384 U.S. 436 (1966).

$155 I d$, at $457-58,467$.

$156 I d$, at $479-81$.

157 Id. at 479. 
of public employment on the answering of questions directly relevant to performance of the job is to place a highly pertinent qualification on the benefit. As has been seen, narrowly drawn conditions may legitimately be attached to benefits if they are necessary to prevent the benefit from being subverted and used to the detriment of the public. ${ }^{15 s}$ By ruling out the use of the statements for prosecution, the Court left the state's interest qua employer intact while protecting the individual's right against compulsory self-incrimination. ${ }^{159}$ Thus the decision in Garrity seems a proper accommodation of the competing interests. ${ }^{100}$

Unfortunately, however, the articulation of the decision belied no such consideration by the Court. In the wake of the sweeping language of Garrity and its companion case, Spevack $v$. Klein, ${ }^{\mathbf{1 0 1}}$ confusion reigned. ${ }^{162}$ Spevack held that the Constitution prohibited disbarment of an attorney for claiming the privilege against self-incrimination at a

158 See notes 80-82 supra and accompanying text.

That the questions be relevant to the individual's performance of official duties is demanded by the general requirement that conditions attached to benefits be narrowly drawn. In Slochower v. Board of Higher Educ., 350 U.S. 551 (1956), the Court held it arbitrary and unreasonable action for a state to dismiss a teacher for having 12 years before invoked the fifth amendment when questioned by a federal body investigating subversive organizations. One crucial factor that distinguished Slochower, however, is that there was no demonstration in Slochower of any relevance of the questions asked to the teacher's competence. In Nelson v. County of Los Angeles, 362 U.S. 1 (1960), and Lerner v. Casey, 357 U.S. 468 (1958), the Supreme Court accepted the state's determination that membership in certain "subversive" organizations was relevant to an evaluation of fitness for public employment. It would seem, however, that in most cases dismissal for refusal to answer questions seeking such information would be unconstitutional. See cases cited notes 76-77 supra. But cf. Pickering v. Board of Educ., 391 U.S. 563, 568 (1968) (different state interests in regulating speech of employees and individuals), quoted note 49 supra; Meehan v. Macy, 392 F.2d 822 (D.C. Cir. 1968) (regulation of speech of policeman).

159 This resolution of the issue prevents infringement of what might be termed the core of the constitutional right-the protection against criminal prosecution through the use of compelled testimony-although encroachment is admittedly made on the penumbra. Cf. Griswold v. Connecticut, 381 U.S. 479, 484 (1965). See Mansfield, The Albertson Case: Conflict Between the Privilege Against Self-Incrimination and the Government's Need for Information, 1966 Sup. CT. REv. 102, 142-43 (P. Kurland ed. 1966).

Sometimes it is well that the privilege bend in order that it not break. The essentials of the privilege are not necessarily sacrificed by requiring disclosure of information when the use to which it is put is controlled and limited.

Id. at 160 .

160 An analogous situation in which accommodation of individual and governmental interests may be necessary involves Rule 16 of the Federal Rules of Criminal Procedure. Mr. Justice Douglas, dissenting to the adoption of the rule, stated:

To deny a defendant the opportunity for discovery. . . merely because the defendant chooses to exercise the constitutional right to refrain from selfincrimination arguably imposes a penalty upon the exercise of that fundamental privilege.

383 U.S. at 1092 . Justice Douglas recognized that "fairness may require disclosure," but indicated that the rule should be narrowly drawn so as to require that the matter discovered be related to that sought to be discovered by the defendant. Id.; see Smith \& McCollom, Connterdiscovery in Criminal Cases: Fifth Amendment Privileges Abridged, 54 A.B.A.J. 256 (1968).

161385 U.S. 511 (1967).

102 See id. at 530-32 (dissenting opinion of Mr. Justice White) ; cf. Uniformed Sanitation Men Ass'n, Inc., v. Commissioner of Sanitation, 392 U.S. 280, 285 (1968) (Harlan, J., concurring). 
judicial inquiry into his conduct. The case might have rested on the grounds that, as the conduct occurred prior to the Court's decision in Garrity, the attorney could not have known that Garrity would bar subsequent prosecution and therefore his refusal to testify at that time was a valid assertion of the right. Under this theory, the state could on remand question him again, and disbar him for continued refusal to speak. ${ }^{163}$ The opinion, however, made no such suggestion, and left open the possibility that states were barred from either prosecuting or removing from employment (by firing, if a state employee, or by withdrawal of a professional license) persons who refused on fifth amendment grounds to testify concerning possible professional misconduct.

Much of the confusion may have been dispelled by two cases decided last term, Gardner v. Broderick ${ }^{164}$ and Uniformed Sanitation Men Association v. Commissioner of Sanitation. ${ }^{165}$ The Court in those cases struck down a provision of the New York City Charter requiring dismissal of public employees ${ }^{166}$ who either claimed the fifth amendment right to refuse to testify or refused to sign a waiver of immunity from prosecution on the basis of their testimony. The issue was whether the state could attempt to coerce a waiver of the immunity conferred by Garrity "on penalty of the loss of employment." 167 Invalidating the provision and the dismissals, both decisions distinguished the case where the employee was not asked to waive his immunity from criminal prosecution but was only required to answer questions relevant to his employment. The Court noted:

If appellant, a policeman, had refused to answer questions specifically, directly, and narrowly relating to the performance

163 The privilege against self-incrimination has been held to be available only where giving testimony may possibly lead to criminal prosecution; where a witness's reasonable fear of prosecution has been removed, the privilege is inapplicable. Ullmann v. United States, 350 U.S. 422, 431 (1956). A judicial expression of immunity by the Supreme Court has recently been available to compel testimony in a state court. In Murphy v. Waterfront Comm'n, 378 U.S. 52 (1964), after holding that any testimony (or the fruits thereof) compelled under a state immunity statute could not be used in a federal prosecution, the Court stated that the reasonable fear of the defendants of possible prosecution had been removed. "It follows that petitioners here may now be compelled to answer the questions propounded to them." Id. at 79. But cf. Mansfield, supra note 159 , at $162-65$, suggesting that information cannot be compelled except pursuant to a statutory grant of immunity. Whenever immunity is extended, however, it must be coextensive with that guaranteed by the fifth amendment. Ullmann v. United States, supra at 430-31. It need not bar all prosecution for any offense disclosed, but only the use of the testimony or its fruits in prosecution. Murphy v. Waterfront Comm'n, supra at 78-79; see id. at 92-107 (White, J., concurring).

164392 U.S. 273 (1968), noted in 46 Geo. L.J. 813 (1968).

165392 U.S. 280 (1968).

160 The charter also provided that they would be permanently ineligible for any employment under the city or any agency thereof. Gardner v. Broderick, 392 U.S. 273, 275 n.3 (1968). The New York State Constitution contained a similar but not identical provision. $I d$.

167 Id. at 279. The Court refused to speculate whether a waiver so compelled would be valid under Garrity. Id. at 278-79. 
of his official duties, without being required to waive his immunity with respect to the use of his answers or the fruits thereof in a criminal prosecution of himself, Garrity v. New Jersey . . . the privilege against self-incrimination would not have been a bar to his dismissal. ${ }^{168}$

The companion case makes it clear that the element of criminal prosecution is the key factor in triggering the privilege: New York was seeking "not merely an accounting . . . of their public trust, but testimony from their own lips which, despite the constitutional prohibition, could be used to prosecute them criminally." 169

In light of Broderick and Uniformed Sanitation Men, then, the situation becomes much clearer. Just as the state can compel production of testimony by contempt sanctions for refusal to disclose, it can likewise compel the testimony by the sanction of dismissal (or withdrawal of a license) for refusal to testify. ${ }^{170}$ In either case, however, if testimony is compelled the individual must be granted immunity from criminal prosecution on the basis of the testimony. ${ }^{171}$ Furthermore, it would appear that at least dismissal of public employees may be based on the testimony thus compelled; that is, such a proceeding is not a "criminal case" within the reach of the immunity. ${ }^{172}$ In both Broderick and

$168 I d$. at 278 (footnote omitted). Similar language is contained in Uniformed Sanitation Men, 392 U.S. at 284.

160 Id. (footnote omitted).

170 Justices Black and Douglas have argued, however, that in their view the fifth amendment's privilege is rooted in the concern for the public ignominy and disgrace to which one is subjected by an admission of guilt, and that therefore it can never be avoided by immunity statutes or rules. Ullmann v. United States, 350 U.S. 422,440 (Douglas \& Black, JJ., dissenting); cf. McKay, Self-Incrimination and the New Privacy, 1967 Sup. CT. Rev. 192, 230 (P. Kurland ed. 1967).

171 Garrity v. New Jersey, 385 U.S. 493 (1967) ; see Murphy v. Waterfront Comm'n, 378 U.S. 52 (1964). 'But cf. George Campbell Painting Corp. v. Reid, 392 U.S. 286 (1968). Campbell Painting involved a challenge to another New York statute, this one requiring that all public contracts contain a clause providing that upon the refusal of any person to testify before a grand jury, answer any relevant question, or waive immunity from subsequent criminal prosecution, such person and any corporation of which he might be a member, officer or director should be disqualified from contracting with any public authority for 5 years, and that any existing public contracts with the person or his corporation could be cancelled with impunity. The Court did not reach the constitutional issue, arguing that the fifth amendment privilege could be raised only by a natural person. Justices Douglas and Black dissented, arguing that no "penalty-direct or collateral-can be imposed on anyone for invoking a constitutional guarantee." Id. at 290 .

172 See Boyd v. United States, 116 U.S. 616 (1886), which, although often cited for the proposition that the privilege is applicable to cases of forfeiture, was explicitly limited to forfeitures imposed as a direct penalty for an offense against the law. Id. at 634 .

In Niedziejko v. Board of Fire \& Police Comm'rs, 33 Wis. 2d 488, 149 N.W.2d 547, cert. denied, 389 U.S. 848 (1967), a post-Garrity decision, the Wisconsin Supreme Court upheld the dismissal of a policeman on the basis of information elicited under threat of discharge. Cf. In re Delahanty, 380 App. Div. 542, 115 N.Y.S.2d 614, aff'd, 304 N.Y. 725, 108 N.E.2d 46 (1952), where contempt sanctions were upheld for a refusal to testify when the individual was subject only to forfeiture of his job with the state. 
Uniformed Sanitation Men, the Court alluded to the propriety of dismissal of employees for failure "to account for their performance of their public trust" where no waiver was required. ${ }^{173}$ These words would seem to imply that a dismissal could be based on the compelled testimony; "account" presumably implies a satisfactory accounting. The Court in Broderick noted that "the policeman is either responsible to the State or to no one." ${ }^{174}$ To rule that the state may discharge an employee for refusing to testify, but that when the testimony reveals incompetent or dishonest performance of duty by its employees, the state must retain them in its service-harming both the state as employer and the public served by the employee-would be to carry the privilege beyond any reasonable bounds. Allowing dismissal under both circumstances would put the state qua employer in the same position as a private employer, while at the same time protecting the private individual's privilege against self-incrimination by providing immunity from prosecution on the basis of his testimony.

A distinction may still exist with respect to the withdrawal of professional licenses held by, for example, lawyers or doctors. Although the states have traditionally been given considerable discretion in the regulation of the practice of law, ${ }^{175}$ language in Broderick seems to indicate that the Court will distinguish between the state's interest as employer in discharging its unfaithful servants and its interest as licensor in disbarring a wayward attorney:

It is argued that although a lawyer could not constitutionally be confronted with Hobson's choice between self-incrimination and forfeiting his means of livelihood, the same principle should not protect a policeman. Unlike the lawyer, he is directly, immediately, and entirely responsible to the city or state which is his employer. He owes his entire loyalty to it. $\mathrm{He}$ has no other "client" or principal. . . .

We agree that these factors differentiate the situations. ${ }^{176}$

Speaking in traditional terminology, the withdrawal of a license is much more akin to punishment than is withdrawal of a job. ${ }^{177}$ If

173 Uniformed Sanitation Men Ass'n v. Commissioner of Sanitation, 392 U.S. 280, 285 (1968); see Gardner v. Broderick, 392 U.S. 273, 278-79 (1968).

174392 U.S. at 278.

175 See, e.g., In re Anastaplo, 366 U.S. 82 (1961) ; Konigsberg v. State Bar, 366 U.S. 36 (1961).

176392 U.S. at 277-78 (footnote omitted).

177 In re Ungar, 26 App. Div. 2d 925, 282 N.Y.S.2d 158, cert. denied sub nom. Ungar v. Association of the Bar, 389 U.S. 1007 (1967), upheld the disbarment of an attorney on the basis of testimony compelled under a grant of immunity from criminal prosecution. If valid, this would suggest that disbarment proceedings are not "criminal" for purposes of the fifth amendment. In Zuckerman v. Greason, 20 N.Y.2d 430, 231 N.E.2d 718, 285 N.Y.S.2d 1 (1967), cert. denied, 390 U.S. 925 (1968), the New York Court of Appeals upheld the suspension of a lawyer on the basis of testi- 
so, then under the Garrity rationale, immunity from disbarment on the basis of the testimony would have to be granted in order to compel testimony by the sanction of disbarment for refusal to testify. ${ }^{178}$ Whether the scope of the privilege is to be extended to encompass this result should be resolved through an analysis of the respective state and individual interests. When a policemar (or garbage man) is discharged, he is not prevented from engaging in similar work for a private company; his job is forfeit, but his means of livelihood is not. When a doctor's or a lawyer's license to practice is withdrawn, he is prevented from engaging in his profession anywhere in the state. In view of the greater significance of the forfeiture and the less direct interest of the state, greater weight may be given to the licensee's interest, tipping the balance in his favor. ${ }^{179}$

\section{A Glance Forward}

Given the recent applications of the doctrine of unconstitutional conditions, the next likely target may well be the practice of guilty plea bargaining, both judicial and prosecutorial.

\section{Judicial Bargaining}

A guilty plea, if induced by promises or threats that deprive it of voluntary character, is void, and a conviction based on such a plea is inconsistent with due process of law. ${ }^{180}$ In harmony with this principle, it has been held that a plea of guilty is involuntary if made subsequent to a judge's statements to a defendant that he will be lenient if a guilty plea is entered and harsh if it is not. ${ }^{181}$ It has also been held that a harsher sentence imposed on a defendant because he persisted in a claim of innocence and insisted that the state prove his guilt is a penalty placed on the exercise of fifth amendment rights, and such a

mony secured under threat of disbarment: "[N] either Garrity nor Spevack confers upon [lawyers] the constitutional privilege to withhold evidence which cannot lead to criminal prosecution and bears only upon their right to continue to practice law." 20 N.Y.2d at $438-39,231$ N.E.2d at 721,285 N.Y.S.2d at 6. But see In re Ruffalo, 390 U.S. 544, 550 (1968): "Disbarment . . . is a punishment or penalty imposed upon the lawyer." Id. at 551: "These are adversary proceedings of a quasi-criminal nature."

178 Presumably, if the state employed the lawyer, it would be able to discharge him on the same reasoning that allows it to discharge the policeman.

178 However, should the rationale developed here with respect to governmental employees prevail as to licensees whose conduct is closely supervised by the state, the residual requirement that the questions asked be relevant to the professional performance would become extremely important to the protection of the first amendment rights of both members and applicants to the bar. Cf. discussion in note 158 sipra and cases cited note 175 supra.

180 See Machibroda v. United States, 368 U.S. 487 (1962); Waley v. Johnston, 316 U.S. 101 (1942).

181 See, e.g., Euziere v. United States, 249 F.2d 293 (10th Cir. 1957) ; United States ex rel. Elksnis v. Gilligan, 256 F. Supp. 244 (S.D.N.Y. 1960); United States v. Tateo, 214 F. Supp. 560 (S.D.N.Y. 1963); cf. United States ex rel. McGrath v. LaVallee, 319 F.2d 308, 319-24 (Marshall, J., dissenting). 
sentence is subject to collateral attack. ${ }^{182}$ Similarly, the denial of consideration for probation because a defendant has asserted the right to trial operates as a penalty upon that right. ${ }^{183}$

It is profitable to view these cases as instances where a positive benefit within the state's granting power-leniency-is conditioned on the non-assertion of a constitutional right-either the right to determination of guilt by trial embodied in the due process clauses or the right to jury trial guaranteed by the sixth amendment. ${ }^{184}$ The exercise of the constitutional right is penalized when an otherwise available benefit is withheld. ${ }^{185}$ Judge Weinfeld, granting a defendant's motion in United States $v$. Tateo ${ }^{186}$ to set aside his conviction on the grounds that his guilty plea had been coerced by improper judicial pressure, stated:

No matter how heinous the offense charged, how overwhelming the proof of guilt may appear, or how hopeless the defense, a defendant's right to continue with his trial may not be violated. His constitutional right to require the Government to proceed to a conclusion of the trial and to establish guilt by independent evidence should not be exercised under the shadow of a penalty-that if he persists in the assertion of his right and is found guilty, he faces, in view of the Trial Court's announced intention, a maximum sentence, and if he pleads guilty, there is the prospect of a substantially reduced term. To impose upon a defendant such alternatives amounts to coercion as a matter of law. ${ }^{187}$

While in Tateo, the defendant had succumbed to the offer, in United States $v$. Wiley ${ }^{188}$ the defendant had insisted on trial and received

182 See Thomas v. United States, 368 F.2d 941 (5th Cir. 1966) (exercise of supervisory power).

183 United States v. Wiley, 278 F.2d 500 (7th Cir. 1960). The case had originally been remanded to the district court for resentencing without the penalty. On the second remand, the district court followed the instructions of the circuit court in 278 F.2d 500 , but not without a lengthy defense of its previous sentencing procedures. United States v. Wiley, 184 F. Supp. 679 (N.D. I1l. 1960). Cf. Gillespie v. State, 355 P.2d 451 (Okla. Comm. App. 1960), where the denial of an application for a suspended sentence was reversed on state law grounds. "A policy designed to deny defendant a suspended sentence solely because he demanded a jury trial is contrary to law and an unjustifiable denial of defendant's rights to have his application for a suspended sentence considered upon its merits." Id. at 456.

184 See note 138 sipra.

185 Although courts have distinguished between threats of punishment and promises of leniency, their coercive impact on defendants is similar, because a threat of punishment is really an implicit promise of benefit if one acts in the desired manner. The distinction is useful, however, if one wishes to take a middle position on the issue of inducing guilty pleas, drawing the line separating the permissible from the invalid at formal prosecutorial bargains embodied in a framework of minimal procedural safeguards.

186214 F. Supp. 560 (S.D.N.Y. 1963).

187 Id. at 567 (footnotes omitted).

188278 F.2d 500 (7th Cir. 1960). 
a consequent penalty when the judge, according to his standard practice, withheld consideration for probation. The defendant who has to make this choice has suffered an interference with the free exercise of a constitutional right regardless of his decision, and has standing to assert a constitutional claim to that effect. ${ }^{189}$

Where convictions or sentences have been reversed because of judicial bargaining as to the form of trial, courts have found the existence of pressure in the record. ${ }^{180}$ While there has been broad language announcing that any suggestion of differential sentencing by judges is coercion as a matter of law ${ }^{191}$ the cases make factual findings regarding coercion of the pleas. Some courts have not found sufficient evidence of coercion in spite of intimidating judicial remarks. ${ }^{192}$ Under the theory of infringement through discouragement that has been advanced in this Comment, however, in any case where it appears that a judge has indicated that he will sentence differently depending on the plea, the state has put the defendant to an unconstitutional choice. ${ }^{193}$ The penalty on assertion and the premium on non-assertion of their

189 One who wishes to raise the issue of infringement in some instances has asserted his rights and has consequently borne a penalty-the revocation or withholding of a benefit. Can he then claim an interference with the free exercise of his constitutional rights? An analogy can be drawn from cases where the Supreme Court has found substantial and immediate injury to individuals challenging statutes for vagueness in the first amendment area. A case from the Fifth Circuit suggests that criminal defendants have standing where they have been deprived of the benefit because of asserting a constitutional right. In Thomas v. United States, 368 F.2d 941 (4th Cir. 1966 ), after trial, the judge advised the defendant that if he persisted in his professions of innocence, he would receive a longer sentence than otherwise. The defendant persisted and received the maximum sentence. In reviewing a denial of his motion for sentence correction by the district court judge, the court of appeals rejected the government's argument that since the defendant had exercised his privilege against selfincrimination, thereby retaining the rights to appeal and to collateral attack, he came through the dilemma "unscathed" and could not protest the sentence. Noting the defendant's "terrible dilemma" the court stated:

When Thomas received harsher punishment than the court would have decreed had he waived his Fifth Amendment rights, he paid a judicially imposed penalty for exercising his constitutionally guaranteed rights.

$I d$. at 946 (footnote omitted). The court specifically disclaimed reaching the constitutional issue, and instead depicted its decision to vacate the sentence as an exercise of its supervisory power over the administration of criminal justice in the federal courts. When it is realized that but for the assertion of the constitutional right, an individual would enjoy a substantial benefit, it seems fair to view him as an appropriate individual to challenge such action as inhibitory of constitutional rights.

190 E.g., Euziere v. United States, 249 F.2d 293 (10th Cir. 1957); United States ex rel. Elksnis v. Gilligan, 256 F. Supp. 244 (S.D.N.Y. 1966) ; United States v. Tateo, 214 F. Supp. 560 (S.D.N.Y. 1963) ; Letters v. Commonwealth, 346 Mass. 403, 193 N.E.2d 578 (1963). Where the record has been uninformative, relief has been denied. See, e.g., United States v. Farrar, 346 F.2d 375 (7th Cir. 1965).

191 See text accompanying note 187 supra.

192 See, e.g., United States v. Cariola, 323 F.2d 180 (3d Cir. 1963); People v. Bernatowicz, 35 Ill. 2d 192, 220 N.E.2d 745 (1966).

193 The fact that a practice that is inimical to constitutional rights is not embodied in a statutory framework makes it no less open to constitutional attack. While embodiment in a statute makes the procedure more susceptible of judicial remedy, because a statute can be simply invalidated, Patton v. North Carolina, 281 F.2d 636 (4th Cir. 1967), cert. denied, 390 U.S. 905 (1968), illustrates the ability of courts to fashion a remedy to prevent: unconstitutional discouragement of rights" through certain nonstatutory practices. 
constitutional rights is sufficient to induce many defendants to abandon them. It may be argued that the withholding of leniency is not a penalty, but the argument is essentially a semantic one, for the effect of withholding a benefit has been recognized to operate as a punishment and a deterrent to the exercise of individual rights.

Whether the judicial practice of sentencing more harshly those who refuse to plead guilty or who demand a jury trial is nevertheless justifiable is still to be considered. While cogent arguments may be advanced that the exigencies of the judicial administration of the criminal system necessitate the maintenance of a system of inducements to pleading guilty, ${ }^{194}$ it is doubtful that judicial bargaining with the defendant is either necessary or desirable for the effectuation of that interest. ${ }^{195}$ First, the judge should symbolize as well as be an impartial arbiter at trial. For him to engage in influencing the defendant in such a manner destroys that image. In an analogous context, the Fourth Circuit has stated, "Even the appearance of improper motivation is a disservice to the administration of justice." ${ }^{196}$ Second, the judge is arguably in a position to exert even more psychological pressure on a defendant than the prosecutor, since he usually passes on the sentence. ${ }^{197}$ Differential sentencing according to plea has been justified on grounds that a guilty plea indicates repentence, ${ }^{198}$ while a sentence after trial often is influenced by implied findings of perjury or a frivolous defense, or by the revelation of dramatic facts during trial. ${ }^{199}$ Yet, differential sentencing on these bases has been shown to be frought with imposing constitutional, statutory, or policy weaknesses. ${ }^{200}$ In sum, the justifications for perpetuation of disparate sentencing by the judiciary, based on waiver or assertion of rights, are weak in view of the discernible discouraging effect that the procedure has on constitutional rights.

194 See text accompanying notes 219-20 infra.

195 See generally Note, Judicial Plea Bargaining, 19 Stan. L. REv. 1082 (1967); Comment, The Influence of the Defendant's Plea on Judicial Determination of Sentence, 66 YALE L.J. 204 (1956).

106 Patton v. North Carolina, 381 F.2d 636, 641 (4th Cir. 1967), cert. denied, 390 U.S. 905 (1968).

197 See, e.g., Commonwealth v. Maroney, $423 \mathrm{~Pa} .337,223$ A.2d 699 (1966) :

"Our concept of due process must draw a distinct line between, on the one hand, advice from and 'bargaining' between defense and prosecuting attorneys and, on the other hand, discussions by judges who are ultimately to determine the length of sentence to be imposed."

Id. at 349,223 A.2d at 705 (quoting United States ex rel. McGrath v. LaVallee, 319 F.2d 308, 319 (2d Cir. 1963) (Marshall, J., dissenting)) (footnote and citation omitted).

198 United States ex rel. Starner v. Russell, 378 F.2d 808 (3d Cir. 1967).

199 Pilot Institute on Sentencing, Proceedings, 26 F.R.D. 231, 287-89 (1959).

200 See Comment, The Influence of the Defendant's Plea on Judicial Determination of Sentence, 66 Y ALE L.J. 204 (1956). 
There still remains the problem of remedy. Although one study has shown that, at least in the federai courts, the majority of judges consider the plea in determining sentence, ${ }^{201}$ whether a particular judge in a particular case has or has not is difficult to determine. One can at least say that whenever the transcript contains remarks by a judge directed to a defendant suggesting that leniency will be extended if a guilty plea is entered, then the conviction should be reversed on the ground that the plea was involuntary as a matter of lawe. Furthermore, whenever the defendant rejected the bargain and the benefit was withheld, which fact could be determined either by the remarks in the record or by clear evidence of disparate sentences between co-defendants explainable only on grounds of differences in pleas, the sentence should be reconsidered. ${ }^{202}$

Where a general practice is tacitly pursued, however, a judicial remedy may be ineffectual, yet the coercive impact on defendant is just as real. Defendants often plead guilty from experience and general anticipation of substantial sentencing benefits. ${ }^{203}$ The low visibility of the phenomenon and the difficulty of a comprehensive solution should not deter a court from announcing a rule of partial effectiveness. By reversing sentences where leniency was clearly withheld or punishment clearly rendered because of the exercise of constitutional rights, the tacit policy may be undermined, because the courts will be less able to trade on the defendant's expectations. Additionally, if judges could not use disparate sentencing to encourage guilty pleas or waiver of jury trial, the utility of judicial sentencing to the state would be diminished. This in turn may help to trigger the demise of judicial sentencing altogether, an attractive prospect for many critics of the criminal adjudicatory system. ${ }^{204}$

$201 \mathrm{Id}$. at 206-07, 222. Tallies of the writers' questionnaire sent to federal judges indicated that (1) $87 \%$ agreed it was accepted practice to sentence more lightly after a guilty plea, and (2) $66 \%$ admitted that they themselves took the plea into account in determining sentence. Also see United States ex rel. Starner v. Russell, 378 F.2d 808, 811-12 (3d Cir. 1967) :

Furthermore, it has always been the rule in both the federal and state system that leniency is always extended on pleas of guilty that is not extended when defendants go to trial, and the petitioner, having had competent counsel, must have been aware of this situation.

See Dewey v. United States, 268 F.2d 124 (8th Cir. 1959).

202 Such evidence was utilized by the court in United States v. Wiley, 278 F.2d 500 (7th Cir. 1960), where a defendant, who was only a minor accessory in the crime, stood trial before a judge and received a 3 -year sentence while his more culpable codefendants, including the ringleader, received sentences of 2 years or less.

203 See D. Newman, Conviction: The Determination of Gutht or Innocence Wrthout TRIAL, 60-66 (1966) [hereinafter cited as Conviction]. This work is the most comprehensive treatment thus far of the entire process of plea bargaining.

204 See, e.g., Dash, Cracks in the Foundation of Criminal Justice, 46 ILd. L. REv. 385,404 (1951) (footnotes omitted) :

A necessary step is the divorcement of the sentencing power from the court. While there are many other reasons why this change in procedure is 


\section{Prosecutorial Bargaining}

It has thus far not been held that the normal bargains of the prosecutor violate constitutional rights of individuals by discouraging the exercise of the right to trial or by penalizing those asserting the right. ${ }^{205}$ Prosecutorial bargaining takes many forms, all of which are directed toward a single objective: persuading the defendant to plead guilty by offering him an irresistible benefit. Prosecutors, for example, will offer to recommend leniency to the judge, to reduce the charge to a lesser included offense, to dismiss another indictment, to do some beneficial act toward someone dear to the defendant, or even to refrain from taking action against such a person. ${ }^{206}$ Although many guilty pleas are the result of bargains, ${ }^{207}$ prosecutorial bargains have often been considered integral elements of the criminal adjudicatory process, ${ }^{208}$ rather than coercive instruments.

necessary for the betterment of the administration of criminal justice, it is in any event a change that will directly wipe out the dangers of the reduced plea. With the court no longer in a position to offer lesser sentences, there will be no advantage to the defendant in pleading guilty to a misdemeanor. .. The trial under such a system will serve its only proper function, the determination of the guilt or innocence of the defendant. Most judges today admit that they are incompetent to sentence. As a result of their insecurity and lack of knowledge in this field, they seize on any pretext to shift the burden, and have welcomed the chance to give light sentences on a plea of guilty to a lesser offense. The sentencing power could be given to a treatment board made up of experts in the fields of psychology, psychiatry, and sociology. Its approach would be on an individualized basis and hinged on the problems and needs of the particular defendant.

205 The Supreme Court refused to consider a case involving a statutorily imposed bargaining system for traffic offenses, for want of a substantial federal question. Marder v. Massachusetts, 346 Mass. 408, 193 N.E.2d 695 (1963), appeal dismissed per ctrriam, 377 U.S. 407 (1964). Justices Douglas and Goldberg dissented. 377 U.S. at 407. Mr. Justice White would have noted probable jurisdiction. Id. The case involved a Massachusetts statute which gave individuals the choice of paying a $\$ 3$ fine or going to trial at the risk of receiving harsher punishment. The Massachusetts Supreme Judicial Court, in upholding the statute against a constitutional due process attack, expressed grave doubts concerning the validity of such a procedure in the case of more serious offenses.

206 See generally Convictron 29; Note, Official Inducements to Plead Guilty: Suggested Morals for a Marketplace, 32 U. CEI. L. Rev. 167 (1964); Note, Guilty Plea Bargaining: Compromises by Prosecutors to Secure Guilty Pleas, 112 U. PA. L. REV. 865, 866-68 (1964). n.7.

207 See Conviction 94, 96; Note, Guilty Plea Bargaining, supra note 206, at 866

208 See, e.g., Cortez v. United States, 337 F.2d 699, 701 (9th Cir. 1964), cert. denied, 381 U.S. 953 (1965) ; Barber v. Gladden, 220 F. Supp. 308, 314 (D. Ore. 1963), aff'd, 327 F.2d 101 (9th Cir.), cert. denied, 377 U.S. 971 (1964). Some courts have taken exception, however, where the prosecutor's bargains have not been kept and have either found pleas "involuntary" on review or found a vaguely defined violation of due process through gross unfairness. See Conviction 36; Note, Guilty Plea Bargaining, supra note 206, at 877-78 (1964). However, it is difficult to see the relevance of whether or not the bargain was kept to an inquiry into the voluntariness of the plea or the constitutionality of a system of official inducements to waive constitutional rights. In Shupe v. Sigler, 230 F. Supp. 601 (D. Neb. 1964), a conviction was reversed even though the prosecutor's bargain not to prosecute the defendant as an habitual criminal was kept. The decision, however, was heavily influenced by the lack of counsel during 
But at least one decision indicates that, in the federal system, guilty pleas can be found lacking in involuntariness to the extent that a bargain by a prosecutor was a motivating force inducing the accused to enter his plea. In Shelton $v$. United States, ${ }^{209}$ two dissenting judges considered the question in the case to be one of due process and of "a fundamental requirement of our system that the machinery of the law in no way be used to bring about the guilty plea and its awful finality unless it represented the general free expression of the prisoner's will." 210 In Shelton the benefit offered was dismissal of an additional count and an indictment in another district along with a recommendation for a specific sentence. When the benefit is release from the risk of a death sentence, there would be additional impetus toward a finding of a coerced plea, but courts have not responded even to this limited extent. ${ }^{211}$

The question of plea bargaining was raised by the briefs before the Supreme Court in United States $v$. Jackson. ${ }^{212}$ The government took the position that by invalidating the federal kidnaping penalty scheme as an impairment of the right to trial and jury trial, the Court would of necessity clear the way for the invalidation of prosecutorial plea bargaining because that procedure similarly offers inducements to individuals to forego constitutional rights. Such a result would "rob the criminal process of much of its flexibility, and would almost certainly lead to generally heavier penalties" for defendants. ${ }^{213}$ The appellee's brief distinguished the Jackson inducement from those of prosecutors on the basis that not all charge reductions and dismissals are inducements, while the federal kidnaping act involves a statutory inducement applicable in all cases. ${ }^{214}$ Additionally, the statutory format

the bargaining process. See $i d$. at 606; cf. Alden v. Montana, 234 F. Supp. 661, 670 (D. Mont. 1964), aff'd, 345 F.2d 530 (9th Cir. 1965). In Harrell v. United States, 371 F.2d 160 (7th Cir.), cert. denied, 387 U.S. 923 (1967), postconviction relief was denied a defendant whose bargain with the prosecutor had not been kept. The court relied heavily on the record, which indicated that the defendant had attested to the voluntariness of his plea at trial and that no promises had been made.

209246 F.2d 571 (5th Cir. 1957) (en banc), rev'd on confession of error by the Solicitor General, 356 U.S. 26 (1958).

210246 F.2d at 580 (Rives \& Brown, JJ., dissenting). It was suggested that the very argument of the majority in favor of the normal practice of plea bargaining concedes that the promises and commitments by prosecutors are effective to induce pleas. Id. at 579.

211 See, e.g., Martin v. United States, 256 F.2d 345 (5th Cir.), cert. denied, 358 U.S. 921 (1958); Commonwealth v. Maroney, 423 Pa. 337, 223 A.2d 699 (1966). 212390 U.S. 570 (1968). See notes 139-44 supra and accompanying text.

213 Brief for Appellant at 6-7, United States v. Jackson, 390 U.S. 570 (1968). The Supreme Court's opinion in Jackson discusses the possibility of forbidding the district courts to accept guilty pleas as one method of correcting the constitutional defect in the federal kidnapping provision. This suggestion was rejected by the Court because to take away the pozver to accept guilty pleas would rob the criminal process of flexibility. 390 U.S. at 584-85. However, the Court did not speak to the issue of plea bargaining, which, even if held to be unconstitutional, would not necessarily preclude courts from accepting guilty pleas by defendants.

214 Brief for Appellee at 9-10, United States v. Jackson, 390 U.S. 570 (1968). 
of the scheme made it readily amenable to remedy, ${ }^{215}$ while the problems of plea bargaining might be, in a practical sense, beyond the reach of judicial review. ${ }^{216}$

In some cases charges are reduced or counts dismissed simply because the original charges were mistaken and as such are not a result of an intention to promote a guilty plea. In others reduction is specifically made to induce the plea. A judicially formulated rule, to effectively prevent prosecutorial inducements might have to take the form of a broad prohibitory rule against any guilty plea which has been preceded by a reduced charge or dismissal of an additional count. While this type of rule would not prevent pre-indictment conferences between the accused and the prosecutor where a bargain may be struck, it would force such bargains to be made under conditions that would diminish the predictability of results between the parties. This would tend to reduce their usefulness to the government and hence their incidence.

It may be argued that the accused will receive harsher treatment under such a rule because he will no longer get the benefit of being charged and sentenced for a crime less severe than that which he committed. The obvious retort is that defendants should not be getting such benefits because it distorts the legislated relationship between punishment and offense. Charge reductions and dismissals have been justified as necessary in order to alleviate unduly harsh legislative provisions. ${ }^{217}$ Ruling out bargained pleas, however, will not prevent the prosecutor from gratuitously using his discretion to reduce indictments. Furthermore, the real focus should be on changing the laws, not on perpetuating a system that may erratically alleviate their effect. While in some cases the prosecutor may be stuck with unrealistically aggravated charges not reducible under the proposed rule, he will soon learn to make well advised decisions about which charges to prosecute. A system freed of plea bargaining would eventually be more beneficial to defendants because the constitutional rights to trial could be exercised in an atmosphere that is in fact free. ${ }^{218}$

215 Id. at 10 . The problem of retroactivity, of course, remains, but since the judgment would be a ruling that is protective in nature, not resting on a specific finding of coercion, but rather on the consideration that rights are likely to be discouraged and no strong countervailing policy is served by perpetuation of the procedure, the benefit of the decision need not be extended retroactively. The appellee's brief stated that since the infringement is against procedural rights, the Court would be free to limit retroactivity. Id. at 30 n.29.

216 The appellee's brief concluded that the possibility that "[a] prosecutor could often avoid even this constellation of restrictions by negotiating with the defendant before the initial charge is framed" might make the charging process "largely beyond the reach of courts." Id. at 10.

217 Conviction 177-82.

218 After exploring the various effects that such a rule would have, the appellee's brief in Jackson states: "About all that would be confined by outlawing charge reductions . . . would be the freedom of the prosecutor to induce the defendant to plead guilty to a crime which he did not commit." Brief for Appellee at 12, United States v. Jackson, 390 U.S. at 570 (1968). 


\section{CONCLUSTON}

The process of both prosecutorial and judicial bargaining parallels those procedures recently invalidated because of the great deterrent pressure they exert on the assertion of constitutional rights. Those who assert their right to trial on the merits are effectively penalized when leniency which would otherwise be accorded is withheld. Yet, analysis is incomplete without an examination of countervailing governmental justifications based on equally fundamental concerns. As has been argued above, such a judgment is both appropriate and indispensable.

It has been repeatedly asserted that prosecutorial plea bargaining is essential to the administration of criminal justice, ${ }^{219}$ and that if it were to be abandoned, the resultant increase in trials would put a severe strain on an already overburdened system. ${ }^{220}$ Administrative costs would soar, and new facilities as well as additional lawyers and judges would be needed. Perhaps most important, the speediness of trials would be drastically affected, leading either to an increase in the period of time spent in pretrial incarceration for many defendants or the release of prisoners who could not be tried consistent with current standards of speediness in trials.

These may, however, turn out to be problems only of a transitional phase, when the system is adjusting to the demands of trying many more individuals accused of crimes. In any event, the Supreme Court, were it to consider the question, would have to weigh (1) the substantiality of the discouragement of the exercise of constitutional rights, (2) the extent to which these rights should be protected, and (3) the countervailing public interest bolstering the present procedure, including whether this interest could be served by less restrictive alternatives. Depending on its faith in the ability of society to marshal resources to approach the constitutional ideal of adjudication of guilt by trial embodied in the fifth amendment and the contemporary evaluations of that ideal, the variables in this equation will be given differing weight.

The doctrine of unconstitutional conditions is an analytical tool for the articulation of the deterrent force in operation when benefits, for example leniency in the criminal process, are conditoned on the waiver of fundamental constitutional rights. But every condition that puts an individual to a difficult choice cannot be deemed un-

219 E.g., Shelton v. United States, 242 F.2d 101, 115 (5th Cir. 1957) (Tuttle, J., dissenting). This opinion became the majority opinion after an en banc hearing. 246 F.2d 571 (5th Cir. 1957), rev'd on confession of error by the Solicitor General, 356 U.S. 26 (1958). See Barber v. Gladden, 220 F. Supp. 308, 314 (D. Ore. 1963) ; Convicrion 39; Note, supra note 206, 881 (1964). Newman announces the sobering statistic that "[r]oughly ninety per cent of all criminal convictions are pleas of guilty." ConvrcTION 3.

220 See Ohlin \& Remington, Sentencing Structure: Its Affect Upon Systems for the Adninistration of Criminal Justice, 23 LAW \& CoNTEMP. PRoB. 495, 500 (1958); Note, Guilty Plea Bargaining, supra note 206, at 881-82. 
constitutional. If that were the case, the doctrine would have become distilled to as rigid a concept as the one it was first developed to combat-the privilege-right dichotomy. In sum, the doctrine provides a useful vocabulary for expressing the causal impact that manipulations of governmental benefits have on individual choices within the ambit of constitutional rights. Lest it assume expansive proportions without logical perimeters, however, it must be utilized with considerable sensitivity to the equities and competing interests in specific constitutional contexts. 